\title{
Annual crop rotation of tropical pastures with no-till soil as affected by lime surface application
}

\author{
Carlos A.C. Crusciol a,*, Rubia R. Marques ${ }^{a}$, Antonio C.A. Carmeis Filho ${ }^{\text {a }}$, \\ Rogério P. Soratto ${ }^{a}$, Claudio H.M. Costa ${ }^{a}$, Jayme Ferrari Neto ${ }^{a}$, Gustavo S.A. Castro ${ }^{b}$, \\ Cristiano M. Pariz ${ }^{\mathrm{c}}$, André M. de Castilhos ${ }^{\mathrm{c}}$ \\ a São Paulo State University (UNESP), College of Agricultural Sciences, Department of Crop Science, P.O. Box: 237, 18610-307 Botucatu, State of São Paulo, \\ Brazil \\ ${ }^{\mathrm{b}}$ Brazilian Agricultural Research Corporation (EMBRAPA), 13070-115 Campinas, State of São Paulo, Brazil \\ c UNESP, School of Veterinary Medicine and Animal Science, Department of Animal Nutrition and Breeding, P.O. Box: 560, 18618-970 Botucatu, State of São \\ Paulo, Brazil
}

\section{A R T I C L E I N F O}

\section{Article history:}

Received 14 March 2016

Received in revised form 6 July 2016

Accepted 12 July 2016

\section{Keywords:}

Acidity

Soil management

Plant nutrition

Net profit

Sustainability of tropical agriculture

\begin{abstract}
A B S T R A C T
Soil acidity and low natural fertility are the main limiting factors for grain production in tropical regions such as the Brazilian Cerrado. The application of lime to the surface of no-till soil can improve plant nutrition, dry matter production, crop yields and revenue. The present study, conducted at the Lageado Experimental Farm in Botucatu, State of São Paulo, Brazil, is part of an ongoing research project initiated in 2002 to evaluate the long-term effects of the surface application of lime on the soil's chemical attributes, nutrition and kernel/grain yield of peanut (Arachis hypogaea), white oat (Avena sativa L.) and maize (Zea mays L.) intercropped with palisade grass (Urochloa brizantha cv. Marandu), as well as the forage dry matter yield of palisade grass in winter/spring, its crude protein concentration, estimated meat production, and revenue in a tropical region with a dry winter during four growing seasons. The experiment was designed in randomized blocks with four replications. The treatments consisted of four rates of lime application $\left(0,1000,2000\right.$ and $\left.4000 \mathrm{~kg} \mathrm{ha}^{-1}\right)$, performed in November 2004 . The surface application of limestone to the studied tropical no-till soil was efficient in reducing soil acidity from the surface down to a depth of $0.60 \mathrm{~m}$ and resulted in greater availability of $\mathrm{P}$ and $\mathrm{K}$ at the soil surface. $\mathrm{Ca}$ and $\mathrm{Mg}$ availability in the soil also increased with the lime application rate, up to a depth of $0.60 \mathrm{~m}$. Nutrient absorption was enhanced with liming, especially regarding the nutrient uptake of $\mathrm{K}$, Ca and $\mathrm{Mg}$ by plants. Significant increases in the yield components and kernel/grain yields of peanut, white oat and maize were obtained through the surface application of limestone. The lime rates estimated to achieve the maximum grain yield, especially in white oat and maize, were very close to the rates necessary to increase the base saturation of a soil sample collected at a depth of $0-0.20 \mathrm{~m}$ to $70 \%$, indicating that the surface liming of $2000 \mathrm{~kg} \mathrm{ha}^{-1}$ is effective for the studied tropical no-till soil. This lime rate also increases the forage dry matter yield, crude protein concentration and estimated meat production during winter/spring in the maize-palisade grass intercropping, provides the highest total and mean net profit during the four growing seasons, and can improve the long-term sustainability of tropical agriculture in the Brazilian Cerrado.
\end{abstract}

(C) 2016 Elsevier B.V. All rights reserved.

\section{Introduction}

No-tillage (NT) is one of the main strategies adopted to mitigate soil degradation. In this production model, the preservation of agricultural ecosystems is the main objective; additionally, this strategy has the potential to recover areas that are already con-

\footnotetext{
* Corresponding author.

E-mail address: crusciol@fca.unesp.br (C.A.C. Crusciol).
}

sidered unproductive. Because of its adaptability and enormous benefits for soil biodiversity, NT has been adopted in various regions of the world, especially in countries such as Argentina, Australia, Brazil, Canada and the United States (Derpsch et al., 2010). The large expansion of NT systems is primarily related to the productivity gains observed in legume and cereal crops.

Soil acidity reduces the availability of nutrients such as calcium $\left(\mathrm{Ca}^{2+}\right)$ and magnesium $\left(\mathrm{Mg}^{2+}\right)$ and increases the bioavailability of toxic elements such as aluminum $\left(\mathrm{Al}^{3+}\right)$ (von Uexküll and Mutert, 1995; Caires et al., 2005). Given these inappropriate conditions for 
crop development, liming is commonly employed to increase the productive potential of soil. However, the low solubility and mobility of limestone in soil cause its diminishing effect on soil acidity to occur slowly once it reaches certain depths in NT soil (Ernani et al., 2004).

In regions with a regular rainfall distribution, several reports have indicated an absence of any response of grain production to surface liming for years (Moreira et al., 2001; Caires et al., 2006a, 2008a,b,c, 2011, 2015; Joris et al., 2013). However, in the tropical regions where dry spells often occur during the rainy season and the dry winter, chemical disorders due to soil and subsoil acidity is an important factor limiting crop productivity (Marsh and Grove, 1992; Sumner, 1995; Castro and Crusciol, 2013a,b; Costa and Crusciol, 2016; Tiritan et al., 2016). This effect has been attributed to the toxic effects of $\mathrm{Al}$ on root growth at certain depths, inducing water stress and nutrient uptake by plants (Caires et al., 2008b). Thus, subsoil acidity alleviation can promote greater root development, increasing the plants' tolerance to water stress during dry spells.

The amount of soil organic matter has been considered an important factor to reduce free Al levels; however, tropical soils such as Oxisols and Ultisols exhibit a naturally low organic matter content. In NT systems, the addition of organic residues helps to regulate $\mathrm{Al}$ species in acid surface soils, but cash crops produce low amounts of straw (Alford et al., 2003; Allen et al., 2007; Zobeck and Schillinger, 2010). In addition, regions with dry winters (low and irregular rainfall), such as the Brazilian Cerrado or African Savanna, have large risks in growing a successful dry-season crop, resulting in a long fallow period without productivity (Borghi et al., 2013). In such warm conditions, straw decomposes rapidly (Nascente et al., 2013; Pariz et al., 2011a), and negatively affects success of NT system.

In NT systems, tropical forages such as palisade grass \{Urochloa brizantha cv. Marandu (Hochst. ex A. Rich.) R.D. Webster [syn. Brachiaria brizantha cv. Marandu (Hochst. ex A. Rich.) Stapf]\} can be available for use in the winter to spring (grazed by animals or cut and removed as fodder) and can be intercropped with grain crops in the summer (Kluthcouski and Aidar, 2003) using an integrated crop-livestock system. Therefore, intercropping maize, sorghum [Sorghum bicolor (L.) Moench], and soybean [Glycine max (L.) Merr.] with tropical perennial grasses is an excellent alternative for producing grain and forage for livestock during the dry season and for increasing the supply of straw for the continuity of NT management (Pariz et al., 2011a,b; Borghi et al., 2013; Crusciol et al., 2011, 2012, 2013, 2014, 2015; Mateus et al., 2016). Consequently, food production is increased without the requirement of cultivating additional areas, and the system is considered sustainable (Sani et al., 2011; Surve and Arvadia, 2011). Most of the agricultural research in tropical and subtropical regions has focused on developing methods to identify liming requirements for soil correction and on determining the rates and application methods that result in higher crop response (Martins et al., 2014a,b). Intercropping grain with forage crops is a new practice, and it requires more information before widespread adoption of the technology (Mateus et al., 2016). Knowledge of species competition for water, light, and nutrients is important for successful grain production and adequate forage availability (Pariz et al., 2011b). For example, understanding the changes in soil chemical attributes and their effects on grain and pasture yield is necessary for establishing and adjusting lime requirements in a crop rotation scheme under NT management (Tiritan et al., 2016).

This study aimed to evaluate the changes in the soil chemical properties, plant nutrition and kernel/grain yield of peanuts, white oat and maize intercropped with palisade grass, as well as forage dry matter yield of palisade grass in winter/spring, its crude protein concentration, estimated meat production, and revenue resulting from superficial liming under no-tillage during four growing seasons in a region with dry winters, such as that of the Brazilian Cerrado.

\section{Materials and methods}

\subsection{Site description and climatic data}

The experiment was conducted from October 2004 to October 2008 at the Lageado Experimental Farm of the College of Agricultural Sciences, FCA/UNESP, in Botucatu, São Paulo State, Brazil. The geographical coordinates of the study site are $48^{\circ} 23^{\prime} \mathrm{W}, 22^{\circ} 51^{\prime} \mathrm{S}$ and the elevation is $765 \mathrm{~m}$. During the experimental period, rainfall was measured daily using a $50 \mathrm{~cm}$ tall plastic rain gauge (pluviometer) placed on the ground at a height of $1.20 \mathrm{~m}$ in the experimental area (Fig. 1).

The soil is classified as a Typic Hapludox (USDA, 2014), with sand, silt, and clay contents of 54,11 , and $35 \%$, respectively, at a depth of $0-0.20 \mathrm{~m}$. The area had been managed since 2002 under a no-till system: in the growing season of 2002/2003, upland rice (Oryza sativa) in the summer and black oat (Avena strigosa Schreb.) in the fall; in the growing season of 2003/2004, common bean (Phaseolus vulgaris L.) in the summer and black oat in the fall.

Prior to the beginning of the experiment (October 2002) and before the last limestone application (August 2004), eight subsamples were randomly obtained from useable areas of each plot at depths of $0-0.05,0.05-0.10,0.10-0.20,0.20-0.40$, and $0.40-0.60 \mathrm{~m}$ and were combined into one composite sample to determine the soil chemical attributes (Table 1 ). The soil $\mathrm{pH}$ was determined in a $0.01 \mathrm{~mol} \mathrm{~L}^{-1} \mathrm{CaCl}_{2}$ suspension (1:2.5 soil/solution). Soil organic matter was determined via the colorimetric method proposed by Haynes (1984) using a sodium dichromate solution. The total acidity at $\mathrm{pH} 7.0(\mathrm{H}+\mathrm{Al})$ was evaluated with $0.5 \mathrm{~mol} \mathrm{~L}^{-1}$ calcium acetate at $\mathrm{pH} 7.0$ and determined through titration with a $0.025 \mathrm{~mol} \mathrm{~L}^{-1} \mathrm{NaOH}$ solution. Exchangeable Al was extracted with neutral $1 \mathrm{~mol} \mathrm{~L}^{-1} \mathrm{KCl}$ at a 1:10 soil/solution ratio and determined by titration with a $0.025 \mathrm{~mol} \mathrm{~L}^{-1} \mathrm{NaOH}$ solution. Available $\mathrm{P}$ and exchangeable $\mathrm{Ca}, \mathrm{Mg}$, and $\mathrm{K}$ were extracted using an ion exchange resin. Exchangeable $\mathrm{Ca}^{2+}, \mathrm{Mg}^{2+}$ and $\mathrm{K}^{+}$were determined using a Shimadzu AA-6300 atomic absorption/Flame-Emission spectrophotometer. Phosphorus was determined calorimetrically (Murphy and Riley, 1962) using a FEMTO 600S spectrophotometer. The cation exchange capacity (CEC) was calculated from the sum of the concentrations of the $\mathrm{H}, \mathrm{Al}, \mathrm{K}, \mathrm{Ca}$, and $\mathrm{Mg}$ cations. Given the low natural level due to the climate conditions and mineralogical composition of the soil (Leal et al., 2009), exchangeable Na was not measured. Base saturation (BS) values were calculated by dividing the sum for $\mathrm{K}, \mathrm{Mg}$, and $\mathrm{Ca}$ (the bases) by the CEC and multiplying the result by $100 \%$ (van Raij et al., 2001).

\subsection{Experimental design}

In this study, we adopted a completely randomized block experimental design with four treatments, replicated six times. The plot size was $5.4 \mathrm{~m} \times 10.0 \mathrm{~m}$. The plots were subjected to four rates of dolomitic limestone application: (i) Control (no lime); (ii) $1.0 \mathrm{Mg} \mathrm{ha}^{-1}$ (half the recommended dose); (iii) $2.0 \mathrm{Mg} \mathrm{ha}^{-1}$ (calculated to raise base saturation to $70 \%$ ); and (iv) $4.0 \mathrm{Mg} \mathrm{ha}^{-1}$ (twice the recommended dose).

\subsection{Establishment of treatments}

At the beginning of the experiment (October 15, 2002), limestone rates were applied superficially. The reapplication on November 2004 was based on a soil analysis that was performed in August 2004, where the base saturation in the treatment in 
Table 1

Chemical characteristics of the soil before the experiment (October 2002) and before the last application (August 2004).

\begin{tabular}{|c|c|c|c|c|c|c|c|c|c|c|}
\hline $\begin{array}{l}\text { Depth } \\
\mathrm{m}\end{array}$ & $\mathrm{pH}\left(\mathrm{CaCl}_{2}\right)$ & $\begin{array}{l}\text { SOM } \\
\mathrm{g} \mathrm{dm}^{-3}\end{array}$ & $\begin{array}{l}\mathrm{P}(\text { resin }) \\
\mathrm{mg} \mathrm{dm}^{-3}\end{array}$ & $\begin{array}{l}\mathrm{H}+\mathrm{Al} \\
\mathrm{mmol}_{\mathrm{c}} \mathrm{dm}^{-3}\end{array}$ & $\mathrm{Al}$ & $\mathrm{K}$ & $\mathrm{Ca}$ & $\mathrm{Mg}$ & CEC & $\begin{array}{l}\text { BS } \\
\%\end{array}$ \\
\hline \multicolumn{11}{|c|}{ October 2002} \\
\hline $0-0.05$ & 5.0 & 27 & 17 & 38 & 4.0 & 1.6 & 28 & 11.7 & 78 & 53 \\
\hline $0.05-0.10$ & 4.9 & 25 & 12 & 40 & 3.7 & 1.0 & 31 & 14.2 & 85 & 54 \\
\hline $0.10-0.20$ & 4.3 & 24 & 7 & 56 & 9.1 & 0.4 & 21 & 8.2 & 85 & 34 \\
\hline $0.20-0.40$ & 3.9 & 22 & 6 & 83 & 17.9 & 0.2 & 18 & 4.8 & 105 & 22 \\
\hline $0.40-0.60$ & 3.9 & 23 & 4 & 100 & 24.8 & 0.2 & 19 & 3.7 & 122 & 18 \\
\hline $0-0.20$ & 4.2 & 21 & 9 & 37 & 6.5 & 1.2 & 14 & 5.0 & 58 & 37 \\
\hline \multicolumn{11}{|c|}{ August 2004} \\
\hline $0-0.05$ & 5.2 & 27 & 61 & 32 & 1.6 & 1.3 & 31 & 15.7 & 79 & 58 \\
\hline $0.05-0.10$ & 4.9 & 26 & 32 & 35 & 2.3 & 1.3 & 23 & 11.9 & 71 & 50 \\
\hline $0.10-0.20$ & 4.6 & 25 & 28 & 44 & 4.8 & 1.1 & 15 & 7.6 & 68 & 36 \\
\hline $0.20-0.40$ & 4.2 & 23 & 14 & 58 & 12.9 & 0.7 & 10 & 4.5 & 73 & 21 \\
\hline $0.40-0.60$ & 4.0 & 23 & 15 & 78 & 17.6 & 0.6 & 8 & 3.2 & 90 & 14 \\
\hline $0-0.20$ & 4.9 & 27 & 35 & 35 & 2.3 & 1.1 & 24 & 10.0 & 70 & 50 \\
\hline
\end{tabular}

Italic values signifies the weighted average of the first three depth.

which the limestone was applied reached $50 \%$, which was the preestablished critical level for decreasing risk ascribed to soil acidity.

The dolomitic limestone rate $(R)$ was calculated to increase base saturation (BS) in the topsoil $(0-20 \mathrm{~cm})$ to $70 \%$, as shown in Eq. (1):

$\mathrm{R}\left(\mathrm{kg} \mathrm{ha}^{-1}\right)=\left(\mathrm{BS}_{2}-\mathrm{BS}_{1}\right) \mathrm{CEC} /(\mathrm{ECCE} / 1000)$

where $\mathrm{BS}_{2}$ is the estimated base saturation (70\%), and $\mathrm{BS}_{1}$ is the base saturation measured in the soil analysis, as shown in Eq. (2):

$\mathrm{BS}_{1}(\%)=\left(\mathrm{Ca}_{\mathrm{ex}}+\mathrm{Mg}_{\mathrm{ex}}+\mathrm{K}_{\mathrm{ex}}\right) 100 / \mathrm{CEC}$

where $\mathrm{Ca}_{\mathrm{ex}}, \mathrm{Mg}_{\mathrm{ex}}$, and $\mathrm{K}_{\mathrm{ex}}$ are basic exchangeable cations, and CEC is the cation exchange capacity, calculated as indicated in Eq. (3):

$\operatorname{CEC}\left(\mathrm{mmol}_{\mathrm{C}} \mathrm{dm}^{-3}\right)=\mathrm{Ca}_{\mathrm{ex}}+\mathrm{Mg}_{\mathrm{ex}}+\mathrm{K}_{\mathrm{ex}}+$ total acidity at $\mathrm{pH} 7.0(\mathrm{H}+\mathrm{Al})$

The dolomitic limestone was composed of $23.3 \% \mathrm{CaO}, 17.5 \%$ $\mathrm{MgO}$, and $71 \%$ effective calcium carbonate equivalents (ECCE). Among the limestone particles, 68.8, 92.4, and 99.7\% passed through 50-, 20-, and 10-mesh sieves, respectively.

\subsection{Crop management and the determination of plant nutrition, yield components, and crop yields}

\subsubsection{Peanut}

The Runner IAC 886 cultivar was sown on 22 Nov., 2004 and 30 Nov., 2005. The peanut seeds were sown in both growing seasons at a spacing of $0.80 \mathrm{~m}$ between rows, with 12 seeds $\mathrm{m}^{-1}$ row using no-till seeding (Semeato, model Personale Drill 13, Passo Fundo, RS, Brazil). Every $100 \mathrm{~kg}$ of seeds was treated with $0.7 \mathrm{~g}$ of the active ingredient (a.i.) thiamethoxam 33-(2-chlorothiazol-5-ylmethyl)-5-methyl-1,3,5-oxadiazinan-4-ylidene (nitro) amine to control Enneothrips flavens. The basic fertilization (at the time of peanut sowing) in the sowing furrows consisted of $24 \mathrm{~kg} \mathrm{ha}^{-1}$ of $\mathrm{N}$ as urea, $84 \mathrm{~kg} \mathrm{ha}^{-1}$ of $\mathrm{P}_{2} \mathrm{O}_{5}$ as triple superphosphate and $48 \mathrm{~kg} \mathrm{ha}^{-1}$ of $\mathrm{K}_{2} \mathrm{O}$ as $\mathrm{KCl}+0.5 \% \mathrm{Zn}+10 \% \mathrm{~S}$ (Ambrosano et al., 1997). Weeds were controlled using $0.4 \mathrm{~kg}$ a.i. ha ${ }^{-1}$ of paraquat $\left\{1,1^{\prime}\right.$-dimethyl-4,4'-bipyridium $\}$ and $0.2 \mathrm{~kg}$ a.i. ha ${ }^{-1}$ of diurom $\{3$ (3,4-dichlorophenyl)-1,1-dimethylurea $1 \mathrm{~d}$ after sowing. $50 \%$ of the plants emerged by $8 \mathrm{~d}$ after sowing in the first growing season and by $10 \mathrm{~d}$ after sowing in the second.

When the peanut plants were at the full-bloom stage, 40 plants were sampled per plot (apical cluster of the main branch), according to Ambrosano et al. (1997). The material was dried in an oven at $65^{\circ} \mathrm{C}$ to constant weight and then ground for macronutrient analyses. The concentrations of $\mathrm{N}, \mathrm{P}, \mathrm{K}, \mathrm{Ca}, \mathrm{Mg}$, and $\mathrm{S}$ were determined using methods described by Malavolta et al. (1997). Nitrogen was determined by the Kjeldahl method. For the determination of other nutrients, milled plant material was mineralized with a nitric-perchloric solution. From this solution, K, Ca, and Mg concentrations were determined using an atomic absorption spectrophotometer. P and S were measured by colorimeter methods using a spectrophotometer (Malavolta et al., 1997).

Peanut harvesting was performed manually on April 07th, 2005 and April 20th, 2006 in the first and second growing season, respectively. Yield components [the final population of plants (number of plants in the two central rows in $8-\mathrm{m}$ rows extrapolated to hectare), the number of filled pods per plant (number of pods in 10 plants), the number of kernels per pod (total number of kernels in 10 plants/total number of pods in 10 plants), the 100 -kernel weight (four samples of 100 kernels) and the hulled-kernel yield (kernel weight/pod weight ratio)] from each plot were determined. Pod yield (moisture content of $90 \mathrm{~g} \mathrm{~kg}^{-1}$ ) was determined by manually harvesting the plants in the two central rows in 8-m rows. Ten peanut plants per plot were sampled for the evaluation of shoot dry matter at ground level.

\subsubsection{White oat}

Before sowing, the test area was desiccated by applying glyphosate (Roundup Original, $1800 \mathrm{~g}$ acid equivalents ha ${ }^{-1}$, Monsanto Brazil). White oat cultivar 'IAC 7' was sown on April 23, 2005 and May 04, 2006. The seeds were sown in both growing seasons at a within-row spacing of $0.17 \mathrm{~m}$, with 133 viable seeds $\mathrm{m}^{-2}$ using no-till seeding (Semeato, model Personale Drill 13, Passo Fundo, RS, Brazil). The basic fertilization (at the time of white oat sowing) in the sowing furrows consisted of $8 \mathrm{~kg} \mathrm{ha}^{-1}$ of $\mathrm{N}$ as urea, $40 \mathrm{~kg} \mathrm{ha}^{-1}$ of $\mathrm{P}_{2} \mathrm{O}_{5}$ as triple superphosphate and $20 \mathrm{~kg} \mathrm{ha}^{-1}$ of $\mathrm{K}_{2} \mathrm{O}$ as $\mathrm{KCl}+7 \%$ S (Cantarella et al., 1997). After sowing was complete, $50 \%$ of the plants emerged by $8 \mathrm{~d}$ in the first growing season and by $7 \mathrm{~d}$ in the second growing season.

Full flowering of plants took place 58 and 66 days after sowing in the first and second growing seasons, respectively. At that stage, 10 plants were sampled for the evaluation of dry matter contents. Additionally, the flag leaves of 50 plants per plot were sampled (Cantarella et al., 1997) for macronutrient determination (N, P, K, Ca, Mg and S) (Malavolta et al., 1997).

White oat was harvested on September 06th, 2005 and September 09th, 2006 in the first and second growing seasons, respectively. Yield components [number of panicles per square meter (number of panicles in the two central rows in 8-m rows), number of spikelets per panicle (number of spikelets in 20 panicles), spikelet fertility (number of grain-bearing spikelets/total number of spikelets per panicle) and 1000-grain weight (four samples of 1000 grains)] from each plot were determined. Grain yield (moisture content of $130 \mathrm{~g} \mathrm{~kg}^{-1}$ ) was determined by manually harvesting the plants in the two central rows in 8-m rows. Ten white oat plants 

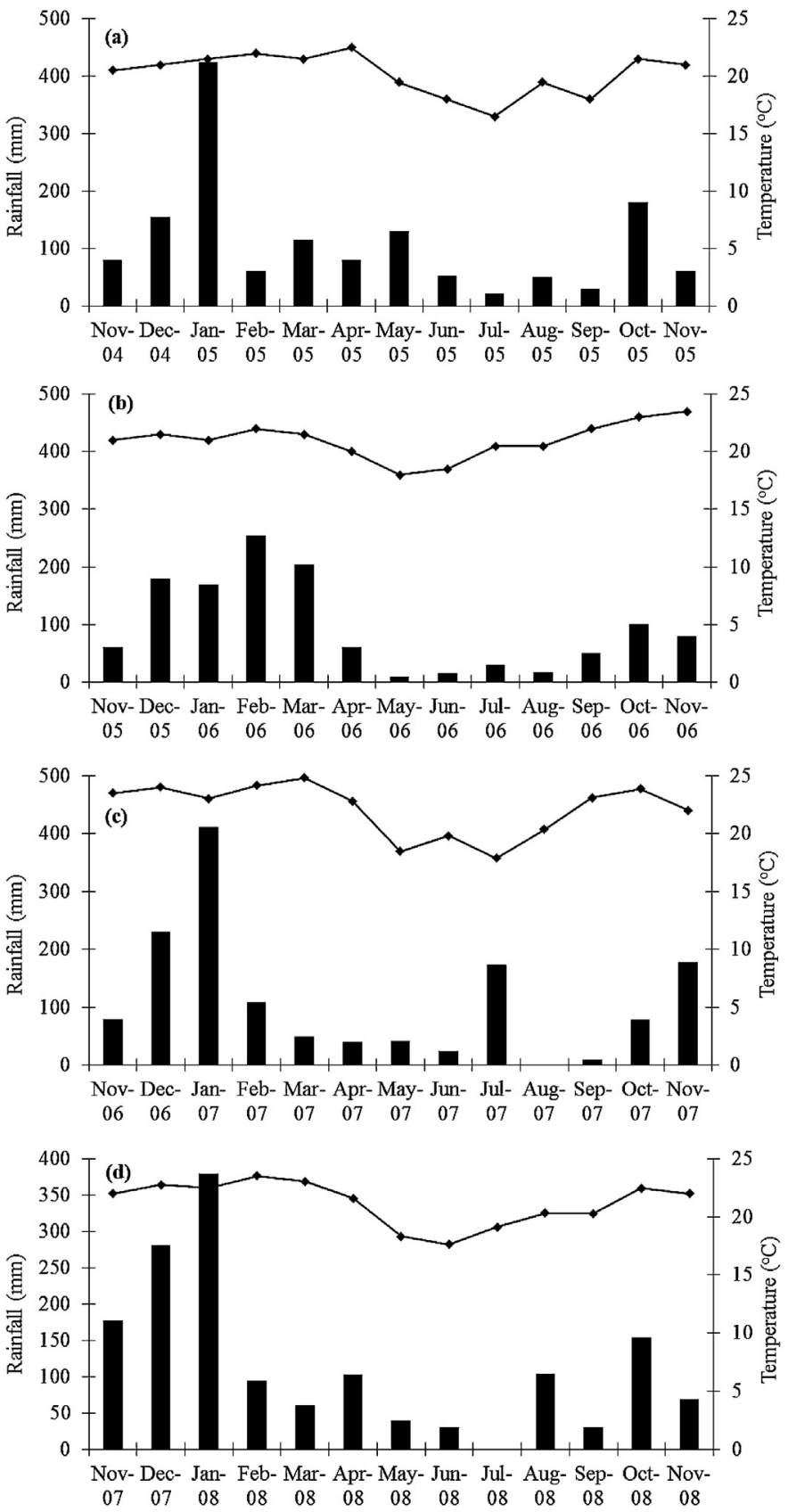

Fig. 1. Monthly rainfall $(\mathrm{mm})$ and average temperature $\left({ }^{\circ} \mathrm{C}\right)$ at the experimental area at Botucatu, São Paulo State, Brazil, during the period from November to November in the agricultural years of (a) 2004-2005, (b) 2005-2006, (c) 2006-2007 and 2007-2008.

per plot were sampled for the evaluation of shoot dry matter at ground level.

\subsubsection{Maize and palisade grass}

Before sowing, the area was desiccated by applying glyphosate (Roundup Original, $1800 \mathrm{~g}$ acid equivalents ha ${ }^{-1}$, Monsanto Brazil). Maize was sown on December 2nd, 2006 and December 10th, 2007, at a depth of $3 \mathrm{~cm}$ using a no-till drill at a density of 66,000 seeds $\mathrm{ha}^{-1}$ and a row spacing of $0.45 \mathrm{~m}$ using no-till seeding (Semeato, model Personale Drill 13, Passo Fundo, RS, Brazil). The hybrid chosen was 2B570, an intermediate maturation-cycle hybrid that required good soil fertility. Every $100 \mathrm{~kg}$ of seeds was treated with $50 \mathrm{~g}$ of the a.i. carboxin \{5,6-dihydro-2-methyl-1,4-oxathi-ine-3carboxanilide $\}$ and $50 \mathrm{~g}$ of the a.i. thiram \{Tetramethylthiuram disulfide to control pests (Aspergillus flavus, Acremonium strictum, Fusarium moniliforme and Penicillium oxalicum). The basic fertilization (at the time of maize sowing) in the sowing furrows consisted of $24 \mathrm{~kg} \mathrm{ha}^{-1}$ of $\mathrm{N}$ as urea, $84 \mathrm{~kg} \mathrm{ha}^{-1}$ of $\mathrm{P}_{2} \mathrm{O}_{5}$ as triple superphosphate and $48 \mathrm{~kg} \mathrm{ha}^{-1}$ of $\mathrm{K}_{2} \mathrm{O}$ as $\mathrm{KCl}$ (Cantarella et al., 1997). Palisade grass was simultaneously sown at densities of $15.3 \mathrm{~kg} \mathrm{ha}^{-1}$ seed (pure live seed $=34 \%$ ). The forage seeds were mixed with base fertilizer (Mateus et al., 2007) and sown at depths of $8 \mathrm{~cm}$ below the soil surface, in the same maize rows, as described by Crusciol et al. (2012).

After sowing, $50 \%$ of the plants had emerged by $5 \mathrm{~d}$ in the first growing season and by $7 \mathrm{~d}$ in the second. During both growing seasons, the side dressing fertilization consisted of $90 \mathrm{~kg} \mathrm{ha}^{-1}$ of $\mathrm{N}$, applied mechanically between rows as urea. At the full-flowering stage, 10 plants per plot were sampled for the evaluation of dry matter contents. Additionally, the central third part of 30 leaves was sampled at the ear base (Cantarella et al., 1997) for macronutrient determination (N, P, K, Ca, Mg and S) (Malavolta et al., 1997).

Maize was harvested on April 1st, 2007 and March 29th, 2008 in the first and second growing seasons, respectively. Yield components [final plant population (number of plants in the two central rows in $8-\mathrm{m}$ rows extrapolated to hectare), number of ears per plant (number of ears in 8-m rows/total number of plants in 8-m rows), number of grains per ear (number of grains in 10 ears) and 100grain weight (eight samples of 100 grains)] from each plot were determined. Grain yield (moisture content of $130 \mathrm{~g} \mathrm{~kg}^{-1}$ ) was determined by manually harvesting the plants in the two central rows in 8 -m rows. Ten corn plants per plot were sampled for the evaluation of shoot dry matter at ground level.

The forage dry matter yield values of palisade grass were evaluated $70 \mathrm{~d}$ (first cut) and $130 \mathrm{~d}$ (second cut) after the maize harvests in June and August, respectively. All forage $(0.25 \mathrm{~m}$ from the soil surface) was cut in three areas of the plots $\left(2 \mathrm{~m}^{2}\right.$ for each area with a row spacing of $0.45 \mathrm{~m}$ ) using a manual mechanical rotary mower. After cutting, all forage was removed from the plots, also using a manual mechanical rotary mower. This cutting height was used to provide faster forage regrowth. The collected material was dried using forced-air circulation at $65^{\circ} \mathrm{C}$ for $72 \mathrm{~h}$. The dry matter was weighed, and the data were extrapolated to $\mathrm{kg} \mathrm{ha}^{-1}$.

For a crude protein evaluation, a sub-sample of palisade grass dry matter was used to determine the nitrogen concentration. Nitrogen was determined by the Kjeldahl method. To calculate the crude protein, the following formula was used: crude protein $(\%)=\% \mathrm{~N} \times 6.25$ (Malavolta et al., 1997).

\subsection{Estimated meat production}

Although grazing by animals was not realized for the palisade grass after the grain maize harvest in the winter/spring, meat production was estimated using the Large Ruminant Nutrition System (LRNS; http://nutritionmodels.tamu.edu/lrns.html) model. The LRNS model is based on the Cornell Net Carbohydrate and Protein System (CNCPS), version 5, as described by Fox et al. (2004). The following factors were used to predict the energy and protein requirements, the performance and the dry matter intake by individual cattle fed in a group: Nellore breed, bull sex, $450 \mathrm{~kg}$ body weight, $52 \%$ of carcass yield, $22 \%$ Body Fat Grading System and continuous grazing. For each treatment, the values of the nutritional palisade grass composition were used to predict the performance values.

The dry matter intake by individual cattle fed in a group was $10.0 \mathrm{~kg}$ of dry matter day ${ }^{-1}$. Due to the high forage crude protein (8.4-12.0\%), the average daily weight gain (ADWG) was based on the allowable metabolizable energy and protein gain. Therefore, the ADWGs were used to estimate the meat production. The dry matter herbage allowance was the double amount of dry matter 
intake by individual cattle, considering a grazing efficiency of $60 \%$, according to Braga et al. (2007).

The time of animal grazing was calculated using a method similar to that used by Crusciol et al. (2012). A period of $365 \mathrm{~d}$ was considered, including an average maize life cycle of $115 \mathrm{~d}$, a 70-d waiting period (an important waiting period after the maize harvest and before animal grazing of palisade grass pasture), and a period of $60 \mathrm{~d}$ after animal grazing on palisade grass pasture for regrowth and desiccation to produce straw under NT management. Therefore, $120 \mathrm{~d}$ ( $365 \mathrm{~d}-115 \mathrm{~d}-70 \mathrm{~d}-60 \mathrm{~d}$ ) were available for animal grazing for all of the treatments ( $60 \mathrm{~d}$ in each cut). Then, the animal stocking rate was estimated from the forage dry matter yield data, the time of animal grazing (days per cut), the dry matter intake by the individual cattle fed in a group and the grazing efficiency. The animal stocking rate was multiplied by ADWG, the time of animal grazing and the carcass yield (52\%) to estimate the total cattle meat produced per hectare.

\subsection{Economic evaluation}

An economic evaluation of each surface-applied dolomitic limestone rate was also conducted. The cost per hectare to produce each crop was calculated (CONAB, 2010). The only difference between treatments was the dolomitic limestone rates used before the peanut crop (November 2004) and the pasture costs as a function of the animal stocking rate. The average peanut, white oat and maize $\mathrm{GY}\left(\mathrm{kg} \mathrm{ha}^{-1}\right)$ and the estimated meat production $\left(\mathrm{kg} \mathrm{ha}^{-1}\right)$ were calculated, and the result was multiplied by the price per $\mathrm{kg}$.

The net profit realization per hectare was calculated using the following formula: (revenue - cost). The total profit and mean net profit were the sum of all growing seasons and the mean by growing season, respectively. We used the Brazilian national average prices from the last five years and converted these values to euro (€) (Agrolink, 2016).

\subsection{Determination of soil chemical characteristics}

Soil chemical characteristics $(\mathrm{pH}, \mathrm{H}+\mathrm{Al}, \mathrm{Al}, \mathrm{P}, \mathrm{Ca}, \mathrm{Mg}, \mathrm{K}$ and base saturation) were evaluated at depths of $0.00-0.05,0.05-0.10$, $0.10-0.20,0.20-0.40$ and $0.40-0.60 \mathrm{~m}$ at twelve and twenty four months after the application of correction material. Six simple samples were collected at random from the useful area of each plot and between rows of the previous crop to form a composite sample. The samples were dried, sieved (2-mm sieves) and analyzed according to van Raij et al. (2001).

\subsection{Statistical analyses}

All data were initially tested for normality using the ShapiroWilk test from the UNIVARIATE procedure of SAS (version 9.3; SAS Inst. Inc., Cary, NC), and the results indicated that all data were distributed normally $(\mathrm{W} \geq 0.90)$. The assumption for the homogeneity of variances was tested using Levene's test for residual errors. When variances could not be considered homogeneous ( $P \leq 0.10)$, Welch's F-test was performed to determine the overall significance for the statistic of interest. The data were then analyzed using the PROC MIXED procedure of SAS and the Satterthwaite approximation to determine the degrees of freedom for the tests of fixed factors. Lime rates were considered fixed factor, and blocks were considered random factor. A repeated statement was used with growing season specified as the repeated variable and block $\times$ lime rates specified as the subject. The covariance structure used in the analyses was autoregressive, which provided the best fit according to the Akaike information criterion. Only the soil results were compared individually for each season (12 and 24 months after lime rates surface reapplication). The results are reported as the least square means and are separated using the probability of differences option (PDIFF). The lime rates were analyzed using the PROC REG procedure of SAS, and the best adjustments were chosen as those with the greatest coefficients of determination and considering the values of the $t$-test. Error bars are presented as standard errors (SEs) and were determined using the PROC MEAN procedure of SAS. The growing season (only for the plant results and estimated meat production) means were compared via Fisher's protected LSD test. The effects of main factor and interaction (lime rates $\times$ growing seasons) were considered statistically significant at $\mathrm{P}<0.05$.

\section{Results}

\subsection{Soil chemical attributes}

After 12 months of superficial liming, a positive effect on the main soil properties was verified (Table 2 ). Notably, the potential $(\mathrm{H}+\mathrm{Al})$ and exchangeable $\left(\mathrm{Al}^{3+}\right)$ acidity were reduced in proportion to the applied carbonate dose; this effect was reflected in the soil $\mathrm{pH}$ values. The effects of superficial liming on $\mathrm{pH}$ levels were observed up to a depth of 0.40-0.60 m after 12 months; however, after 24 months, the effect was limited to the upper $0.20 \mathrm{~m}$. Although there were no differences in $\mathrm{pH}$ values, reductions in potential and exchangeable acidity were observed down to $0.60 \mathrm{~m}$ depth after 24 months.

Liming also increased macronutrient availability in soil. Regarding the effects on the availability of phosphorus, calcium, potassium and magnesium, after 12 months, the correction raised $\mathrm{P}, \mathrm{Ca}$ and $\mathrm{Mg}$ in all layers evaluated; however, $\mathrm{K}$ availability was unchanged in the deeper layers (0.20-0.40 and 0.40-0.60 m). After 24 months, the correction increased the levels of $\mathrm{K}, \mathrm{Ca}, \mathrm{Mg}$ and $\mathrm{P}$ at depths down to $0.60 \mathrm{~m}$. The increase in the $\mathrm{K}, \mathrm{Ca}$ and $\mathrm{Mg}$ levels was also positively reflected in base saturation values (BS\%) down to $0.60 \mathrm{~m}$.

\subsection{Peanut, white oat, and maize nutrition}

Superficial liming increased the foliar concentrations of N, P, K, $\mathrm{Ca}$ and $\mathrm{Mg}$ in peanut; the effect for $\mathrm{K}, \mathrm{Ca}$ and $\mathrm{Mg}$ was linear, while $\mathrm{N}$, $P$ and $S$ were better explained by a quadratic equation (Fig. 2a-e). In the first growing season, the N, P and $\mathrm{K}$ concentrations were lower than in the second growing season, while for the other nutrients, no effect of the growing season was observed (Table 3 ). The improvement of plant nutrition with liming was reflected in greater shoot dry matter production (Fig. 3a); in addition, the second growing season plants showed more vegetative development.

In the white oat crop, quadratic responses of $\mathrm{K}, \mathrm{Mg}$ and $\mathrm{S}$ were verified (Fig. 4a-d) as well as linear responses for the Ca concentrations (Fig. 4b). However, it was observed that the second growing season showed the highest macronutrient concentration in the leaves, except for $\mathrm{N}$ and $\mathrm{S}$ (Table 4). Shoot dry matter production was influenced by both factors, with a quadratic increase being observed for liming (Fig. 5a and d) and superior results in the first growing season.

Regarding maize nutrition, higher concentrations of all macronutrients were observed in the second growing season (Table 5). Positive responses were also associated with liming for all nutrients except for P (Fig. 6). As observed for the peanut and white oat crops, shoot dry matter production in maize was also increased with liming, and the highest production occurred in the second growing season.

\subsection{Peanut, white oat, and maize components and kernel/grain yield}

Liming positively affected the yield components and kernel/grain yield of peanut, white oat and maize (Tables $3-5$ ). In 
Table 2

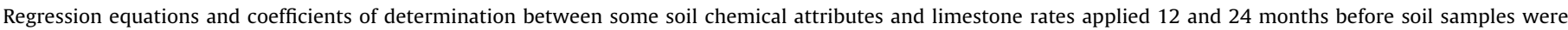
collected from a long-term no-till soil and ANOVA significance.

\begin{tabular}{|c|c|c|c|c|c|c|c|}
\hline \multirow[t]{2}{*}{ Soil depth (m) } & \multicolumn{4}{|c|}{ Limestone rate, $\mathrm{kg} \mathrm{ha}^{-1}$} & \multirow[t]{2}{*}{ Regression } & \multirow[t]{2}{*}{$\mathrm{R}^{2}$} & \multirow[t]{2}{*}{$\operatorname{ANOVA}(\mathrm{p}>\mathrm{F})$} \\
\hline & 0 & 1000 & 2000 & 4000 & & & \\
\hline & $\mathrm{pH}(\mathrm{C}$ & months & & & & & \\
\hline $0-0.05$ & 4.5 & 4.6 & 5.0 & 5.2 & $y=0.00017 x+4.5$ & 87.8 & 0.0091 \\
\hline $0.05-0.10$ & 4.2 & 4.5 & 4.8 & 5.2 & $y=0.000243 x+4.25$ & 99.5 & $<0.0001$ \\
\hline $0.10-0.20$ & 3.9 & 4.1 & 4.2 & 4.6 & $y=0.00016 x+3.895$ & 96.9 & 0.0014 \\
\hline $0.20-0.40$ & 3.5 & 3.7 & 3.9 & 4.0 & $\mathrm{y}=0.0001 \mathrm{x}+3.56$ & 89.5 & 0.0328 \\
\hline \multirow[t]{2}{*}{$0.40-0.60$} & 3.6 & 3.7 & 3.9 & 4.1 & $y=0.0001 x+3.6$ & 98.1 & 0.0064 \\
\hline & $\mathrm{pH}(\mathrm{C}$ & months & & & & & \\
\hline $0-0.05$ & 4.7 & 5.0 & 5.6 & 6.1 & $y=0.00037 x+4.74$ & 97.3 & $<0.0001$ \\
\hline $0.05-0.10$ & 4.6 & 4.8 & 5.2 & 6.0 & $y=0.000358 x+4.53$ & 99.1 & $<0.0001$ \\
\hline $0.10-0.20$ & 4.3 & 4.4 & 4.5 & 5.0 & $y=0.00018 x+4.27$ & 93.5 & $<0.0001$ \\
\hline $0.20-0.40$ & 4.0 & 4.2 & 4.3 & 4.3 & - & - & ns \\
\hline \multirow[t]{2}{*}{$0.40-0.60$} & 4.0 & 4.0 & 4.1 & 4.1 & - & - & ns \\
\hline & $\mathrm{H}+\mathrm{Al}$ & & & & & & \\
\hline $0-0.05$ & 58 & 45 & 27 & 19 & $y=-0.009671 x+53.86$ & 90.6 & $<0.0001$ \\
\hline $0.05-0.10$ & 83 & 50 & 45 & 34 & $\mathrm{y}=-0.011 \mathrm{x}+71.81$ & 76.7 & $<0.0001$ \\
\hline $0.10-0.20$ & 85 & 70 & 53 & 44 & $y=-0.01 x+80.37$ & 90.9 & $<0.0001$ \\
\hline $0.20-0.40$ & 167 & 104 & 90 & 70 & $y=9 E^{-06} x^{2}-0.0578 x+163.35$ & 96.5 & $<0.0001$ \\
\hline \multirow[t]{2}{*}{$0.40-0.60$} & 145 & 105 & 80 & 69 & $\mathrm{y}=7 \mathrm{E}^{-06} \mathrm{x}^{2}-0.047 \mathrm{x}+145.26$ & 99.9 & 0.0016 \\
\hline & $\mathrm{H}+\mathrm{Al}$ & & & & & & \\
\hline $0-0.05$ & 47 & 40 & 23 & 15 & $y=1 E-06 x^{2}-0.0141 x+48.76$ & 94.5 & $<0.0001$ \\
\hline $0.05-0.10$ & 50 & 48 & 41 & 27 & $y=-0.006 x+52.273$ & 97.1 & $<0.0001$ \\
\hline $0.10-0.20$ & 71 & 69 & 54 & 43 & $y=-0.0076 x+72.56$ & 94.3 & $<0.0001$ \\
\hline $0.20-0.40$ & 93 & 83 & 71 & 63 & $y=-0.00756 x+90.60$ & 93.0 & $<0.0001$ \\
\hline \multirow[t]{2}{*}{$0.40-0.60$} & 109 & 103 & 96 & 82 & $y=-0.0069 x+109.8$ & 99.9 & $<0.0001$ \\
\hline & Exch & $\mathrm{Al}^{3+}, 12$ & & & & & \\
\hline $0-0.05$ & 1.6 & 1.6 & 1.2 & 1.1 & $\mathrm{y}=-0.000131+1.61$ & 85.2 & $<0.0001$ \\
\hline $0.05-0.10$ & 4.2 & 2.1 & 1.6 & 1.1 & $y=-0.000688 x+3.44$ & 76.1 & $<0.0001$ \\
\hline $0.10-0.20$ & 4.5 & 3.5 & 2.4 & 1.9 & $y=-0.00064 x+4.16$ & 88.7 & $<0.0001$ \\
\hline $0.20-0.40$ & 8.5 & 7.8 & 6.8 & 5.8 & $y=-0.00068 x+8.40$ & 98.6 & 0.0146 \\
\hline \multirow[t]{2}{*}{$0.40-0.60$} & 9.1 & 8.4 & 7.1 & 6.4 & $y=-0.00068 x+8.91$ & 93.3 & $<0.0001$ \\
\hline & Exch & $\mathrm{Al}^{3+}, 24$ & & & & & \\
\hline $0-0.05$ & 2.4 & 1.4 & 1.4 & 1.1 & $\mathrm{y}=1 \mathrm{E}^{-07} \mathrm{x}^{2}-0.0007 \mathrm{x}+2.27$ & 91.0 & 0.0041 \\
\hline $0.05-0.10$ & 3.4 & 2.2 & 1.9 & 1.3 & $\mathrm{y}=1 \mathrm{E}^{-07} \mathrm{x}^{2}-0.001 \mathrm{x}+3.2758$ & 97.0 & 0.0225 \\
\hline $0.10-0.20$ & 6.4 & 5.6 & 4.7 & 2.6 & $y=-0.00095 x+6.48$ & 99.5 & $<0.0001$ \\
\hline $0.20-0.40$ & 11.2 & 10.3 & 8.7 & 7.8 & $\mathrm{y}=-0.00088+11.02$ & 93.3 & 0.0049 \\
\hline \multirow[t]{2}{*}{$0.40-0.60$} & 13.4 & 12.6 & 12.4 & 11.0 & - & - & ns \\
\hline & P resi & ths & & & & & \\
\hline $0-0.05$ & 27.6 & 36.1 & 41.6 & 50.4 & $y=0.0055 x+29.25$ & 97.3 & $<0.0001$ \\
\hline $0.05-0.10$ & 11.4 & 16.5 & 18.9 & 24.7 & $y=0.0032 x+12.26$ & 97.7 & $<0.0001$ \\
\hline $0.10-0.20$ & 8.2 & 8.5 & 10.7 & 12.2 & $y=0.0011 x+7.987$ & 93.7 & $<0.0001$ \\
\hline $0.20-0.40$ & 3.8 & 4.6 & 5.1 & 5.8 & $y=0.00048 x+4.00$ & 96.0 & $<0.0001$ \\
\hline $0.40-0.60$ & 3.8 & 5.2 & 5.2 & 9.3 & $y=0.0013 x+3.54$ & 92.2 & $<0.0001$ \\
\hline & P resi & ths & & & & & \\
\hline $0-0.05$ & 26 & 34 & 46 & 55 & $y=0.0075 x+27.08$ & 96.2 & $<0.0001$ \\
\hline $0.05-0.10$ & 15 & 20 & 33 & 23 & $y=-3 E^{-06} x^{2}+0.0135 x+13.37$ & 81.1 & $<0.0001$ \\
\hline $0.10-0.20$ & 5.8 & 7.8 & 12.0 & 12.9 & $\mathrm{y}=-5 \mathrm{E}^{-07} \mathrm{x}^{2}+0.0039 \mathrm{x}+5.40$ & 94.8 & 0.0071 \\
\hline $0.20-0.40$ & 2.4 & 2.7 & 3.1 & 4.2 & $\mathrm{y}=0.00045 \mathrm{x}+2.31$ & 98.1 & $<0.0001$ \\
\hline $0.40-0.60$ & 2.1 & 2.4 & 2.6 & 2.9 & $y=0.0002 x+2.14$ & 94.9 & 0.0044 \\
\hline & Exch & $\mathrm{K}^{+}, 12 \mathrm{n}$ & & & & & \\
\hline $0-0.05$ & 3.4 & 3.5 & 4.8 & 4.2 & $\mathrm{y}=-2 \mathrm{E}^{-07} \mathrm{x}^{2}+0.001 \mathrm{x}+3.23$ & 66.0 & 0.0011 \\
\hline $0.05-0.10$ & 2.2 & 2.5 & 3.2 & 2.7 & $\mathrm{y}=-2 \mathrm{E}^{-07} \mathrm{x}^{2}+0.0008 \mathrm{x}+2.09$ & 85.5 & 0.0122 \\
\hline $0.10-0.20$ & 2.0 & 2.1 & 2.3 & 2.4 & $\mathrm{y}=0.00011 \mathrm{x}+2.023$ & 83.7 & 0.0132 \\
\hline $0.20-0.40$ & 2.0 & 2.2 & 2.2 & 2.2 & - & - & ns \\
\hline $0.40-0.60$ & 2.0 & 2.0 & 2.3 & 2.3 & - & - & ns \\
\hline & Exch & $K^{+}, 24 n$ & & & & & \\
\hline $0-0.05$ & 1.4 & 2.5 & 3.4 & 2.3 & $y=-4 E^{-07} x^{2}+0,0017 x+1,3647$ & 96.5 & $<0.0001$ \\
\hline $0.05-0.10$ & 0.9 & 1.0 & 2.3 & 1.2 & $y=-2 E^{-07} x^{2}+0.0011 x+0.68$ & 62.1 & $<0.0001$ \\
\hline $0.10-0.20$ & 0.5 & 0.7 & 1.0 & 0.8 & $y=-6 E^{-08} x^{2}+0.0003 x+0.450$ & 88.1 & 0.0018 \\
\hline $0.20-0.40$ & 0.3 & 0.4 & 1.0 & 0.5 & $\mathrm{y}=-1 \mathrm{E}^{-07} \mathrm{x}^{2}+0.0005 \mathrm{x}+0.19$ & 76.2 & $<0.0001$ \\
\hline $0.40-0.60$ & 0.3 & 0.4 & 0.5 & 0.6 & $y=0.00008 x+0.31$ & 95.2 & 0.0009 \\
\hline & Exch & $\mathrm{Ca}^{2+}, 12$ & & & & & \\
\hline $0-0.05$ & 14 & 28 & 46 & 66 & $y=0,013 x+15.66$ & 98.0 & $<0.0001$ \\
\hline $0.05-0.10$ & 10 & 17 & 25 & 32 & $\mathrm{y}=0.00554 \mathrm{x}+11.28$ & 94.5 & $<0.0001$ \\
\hline $0.10-0.20$ & 10 & 14 & 15 & 18 & $y=0.00183 x+10.864$ & 90.8 & $<0.0001$ \\
\hline $0.20-0.40$ & 6.6 & 7.4 & 9.1 & 9.1 & $y=0.00064 x+6.90$ & 76.9 & 0.0014 \\
\hline $0.40-0.60$ & 6.1 & 7.8 & 9.1 & 10.3 & $y=0.001 x+6.536$ & 94.1 & $<0.0001$ \\
\hline
\end{tabular}


Table 2 (Continued)

\begin{tabular}{|c|c|c|c|c|c|c|c|}
\hline \multirow[t]{2}{*}{ Soil depth (m) } & \multicolumn{4}{|c|}{ Limestone rate, $\mathrm{kg} \mathrm{ha}^{-1}$} & \multirow[t]{2}{*}{ Regression } & \multirow[t]{2}{*}{$\mathrm{R}^{2}$} & \multirow[t]{2}{*}{ ANOVA $(\mathrm{p}>\mathrm{F})$} \\
\hline & 0 & 1000 & 2000 & 4000 & & & \\
\hline & \multicolumn{7}{|c|}{ Exchangeable $\mathrm{Ca}^{2+}, 24$ months } \\
\hline $0-0.05$ & 17.9 & 35.4 & 60.6 & 82.2 & $y=0.016 x+20.58$ & 96.8 & $<0.0001$ \\
\hline $0.05-0.10$ & 15.4 & 21.4 & 24.7 & 40.1 & $y=0.0061 x+14.72$ & 97.9 & $<0.0001$ \\
\hline $0.10-0.20$ & 11.6 & 13.0 & 14.2 & 26.6 & $y=0.0038 x+9.73$ & 88.5 & $<0.0001$ \\
\hline $0.20-0.40$ & 7.7 & 9.1 & 10.0 & 10.5 & $y=0.00067 x+8.15$ & 85.3 & 0.0029 \\
\hline \multirow[t]{2}{*}{$0.40-0.60$} & 6.3 & 6.6 & 7.5 & 8.4 & $y=0.0005 x+6.24$ & 97.5 & 0.0033 \\
\hline & \multicolumn{7}{|c|}{ Exchangeable $\mathrm{Mg}^{2+}, 12$ months } \\
\hline $0-0.05$ & 7.7 & 15.9 & 29.6 & 36.6 & $y=0.00735 x+9.582$ & 92.5 & $<0.0001$ \\
\hline $0.05-0.10$ & 4.9 & 8.1 & 9.5 & 24.3 & $y=0.0048 x+3.268$ & 92.1 & $<0.0001$ \\
\hline $0.10-0.20$ & 5.2 & 7.3 & 10.9 & 12.5 & $y=0.001857 x+5.73$ & 91.4 & $<0.0001$ \\
\hline $0.20-0.40$ & 2.7 & 3.3 & 4.5 & 5.0 & $y=0.00059 x+2.82$ & 91.8 & $<0.0001$ \\
\hline \multirow[t]{2}{*}{$0.40-0.60$} & 3.0 & 3.6 & 4.3 & 5.1 & $y=0.00053 x+3.055$ & 98.7 & $<0.0001$ \\
\hline & \multicolumn{7}{|c|}{ Exchangeable $\mathrm{Mg}^{2+}, 24$ months } \\
\hline $0-0.05$ & 11.4 & 16.5 & 25.0 & 35.3 & $y=0.0061 x+11.38$ & 99.1 & $<0.0001$ \\
\hline $0.05-0.10$ & 9.2 & 10.5 & 14.7 & 21.5 & $y=0.0032 x+8.37$ & 97.9 & $<0.0001$ \\
\hline $0.10-0.20$ & 7.4 & 8.8 & 8.9 & 15.7 & $y=0.002 x+6.58$ & 88.1 & $<0.0001$ \\
\hline $0.20-0.40$ & 5.0 & 6.0 & 6.0 & 7.1 & $y=0.00049 x+5.16$ & 92.7 & $<0.0001$ \\
\hline \multirow[t]{2}{*}{$0.40-0.60$} & 3.6 & 3.9 & 4.1 & 4.2 & $y=0.00015 x+3.70$ & 87.6 & 0.0192 \\
\hline & \multicolumn{7}{|c|}{ Base saturation, 12 months } \\
\hline $0-0.05$ & 30 & 52 & 75 & 85 & $y=-0.000004 x^{2}+0.029 x+29.26$ & 99.1 & $<0.0001$ \\
\hline $0.05-0.10$ & 17 & 36 & 46 & 64 & $y=0.01123 x+20.915$ & 96.3 & $<0.0001$ \\
\hline $0.10-0.20$ & 17 & 25 & 35 & 43 & $y=0.00645 x+18.53$ & 94.9 & $<0.0001$ \\
\hline $0.20-0.40$ & 6 & 11 & 15 & 19 & $y=0.003 x+7.46$ & 95.2 & $<0.0001$ \\
\hline \multirow[t]{2}{*}{$0.40-0.60$} & 7 & 11 & 17 & 20 & $y=-6 E^{-07} x^{2}+0.0057 x+6.90$ & 99.3 & 0.0044 \\
\hline & \multicolumn{7}{|c|}{ Base saturation, 24 months } \\
\hline $0-0.05$ & 40 & 57 & 80 & 89 & $y=-3 E^{-06} x^{2}+0.026 x+38.16$ & 98.4 & $<0.0001$ \\
\hline $0.05-0.10$ & 34 & 41 & 50 & 70 & $y=0.0092 x+32.54$ & 99.5 & $<0.0001$ \\
\hline $0.10-0.20$ & 22 & 25 & 31 & 50 & $\mathrm{y}=1 \mathrm{E}^{-06} \mathrm{x}^{2}+0.002 \mathrm{x}+21.48$ & 99.9 & $<0.0001$ \\
\hline $0.20-0.40$ & 12 & 16 & 19 & 22 & $y=0.0025 x+13.06$ & 94.8 & $<0.0001$ \\
\hline $0.40-0.60$ & 8 & 9 & 11 & 14 & $y=0.00137 x+8.40$ & 99.2 & $<0.0001$ \\
\hline
\end{tabular}

Table 3

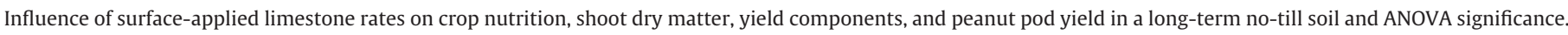

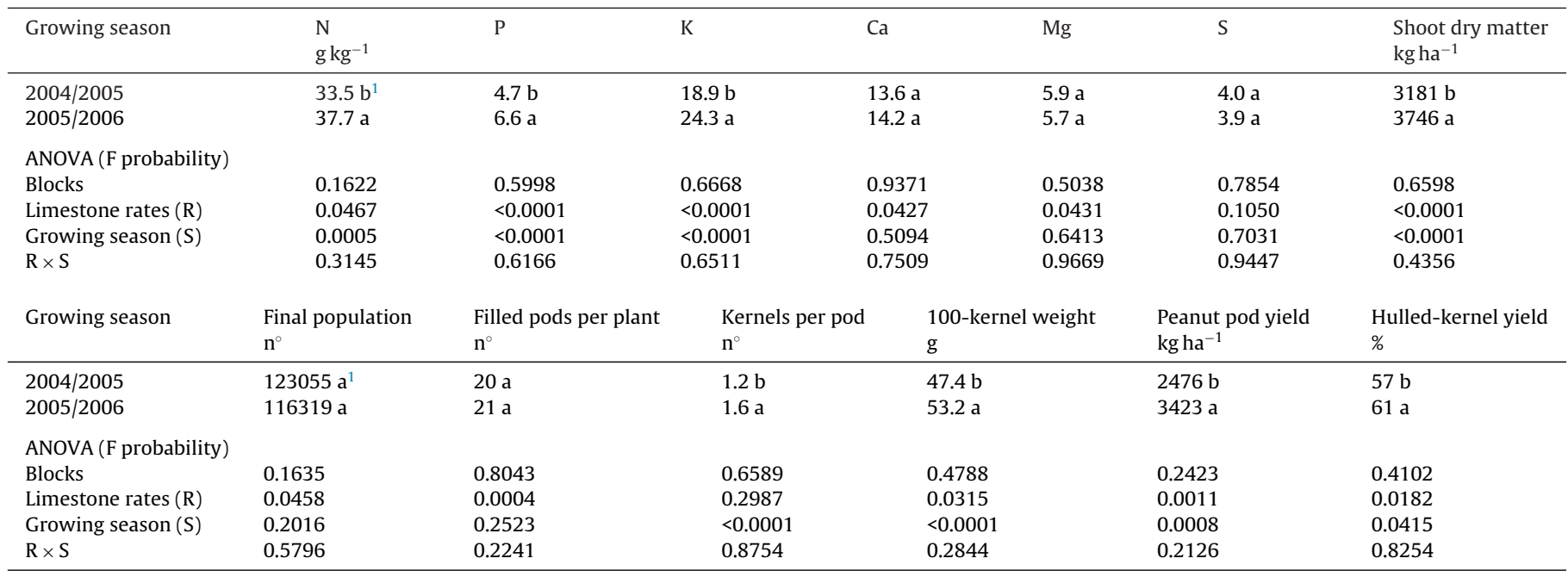

${ }^{1}$ Means followed by different letters in the column differ statistically by the LSD test $(\mathrm{p}<0.05)$.

peanut, except for the 100-kernel weight, which responded linearly (Fig. 3d), and the number of kernels per pod, which was not affected, shoot dry matter, number of plants per hectare and all reproductive parameters were explained by quadratic equations (Fig. 3a-f) and the maximum hulled-kernel yield (62\%) was achieved under $2800 \mathrm{~kg} \mathrm{ha}^{-1}$ of lime application. Moreover, more kernels per pod and a higher 100-kernel weight were observed in the second cropping season, with a positive impact on the kernel yield and hulled-kernel yield.

In white oat, liming also positively affected the number of panicles per square meter and the number of spikelets per panicle
(Fig. 5b and c); these increases were reflected in the grain yield (Fig. 5d). All these relationships were quadratic and the maximum grain yield ( $3191 \mathrm{~kg} \mathrm{ha}^{-1}$ ) was achieved under $2000 \mathrm{~kg} \mathrm{ha}^{-1}$ of lime application. Regarding the growing season, it is important to note that environmental conditions in the second growing season favored the plants' development, resulting in better growth and development of reproductive structures (number of panicles and spikelets), leading to a higher yield.

For the maize crop, the grain yield increased quadratically with lime application, due to its beneficial effects on stand establishment and the increased development of reproductive structures 

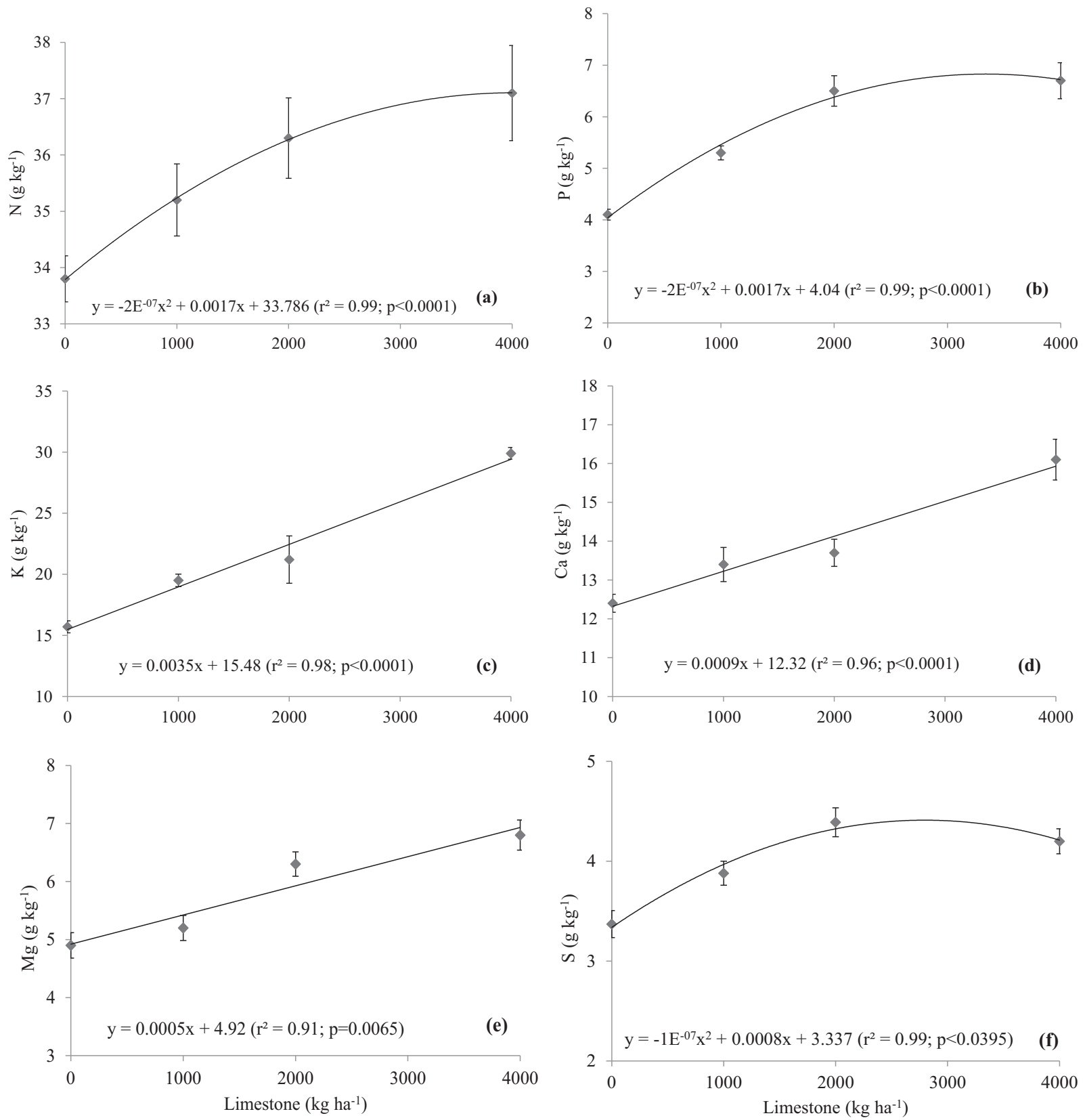

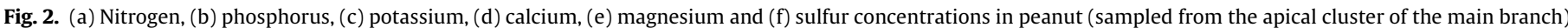

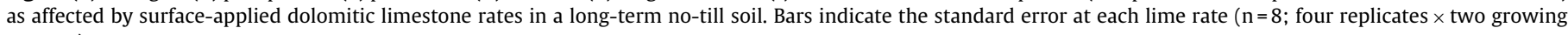
seasons).

(Fig. 7a-c). In the second growing season, the values for all production components were higher, with a significant increase in the grain yield of $2542 \mathrm{~kg} \mathrm{ha}^{-1}$ being recorded.

\subsection{Forage characteristics and estimated meat production}

In the first and second cuttings, the forage dry matter yield was influenced by the interaction of lime rate $\times$ growing season (Table 6). In the first and second cuttings, crude protein was influenced by the lime rates. In the first and second cuttings and in the total of both cuttings, the estimated meat production was influenced by the interaction of lime rate $\times$ growing season. All results of forage dry matter yield, crude protein and estimated meat production were quadratically related to the lime rate (Figs. 8 and 9).

\subsection{Economic evaluation}

The lowest total profit and mean net profit $\left(0 \mathrm{~kg} \mathrm{ha}^{-1}, € 1198\right.$ and $€ 299$ per ha, respectively) were achieved with no surface application of dolomitic limestone, and a rate of $2000 \mathrm{~kg} \mathrm{ha}^{-1}$ of dolomitic limestone resulted in the highest total and mean net profit ( $€ 4064$ and $€ 1016$ per ha, respectively) (Table 7).

\section{Discussion}

\subsection{Soil chemical attributes}

Despite the low solubility and mobility of limestone in the soil, effects of superficial liming were observed at depths down to $0.60 \mathrm{~m}$ after 12 months, with a significant reduction in the active acid- 

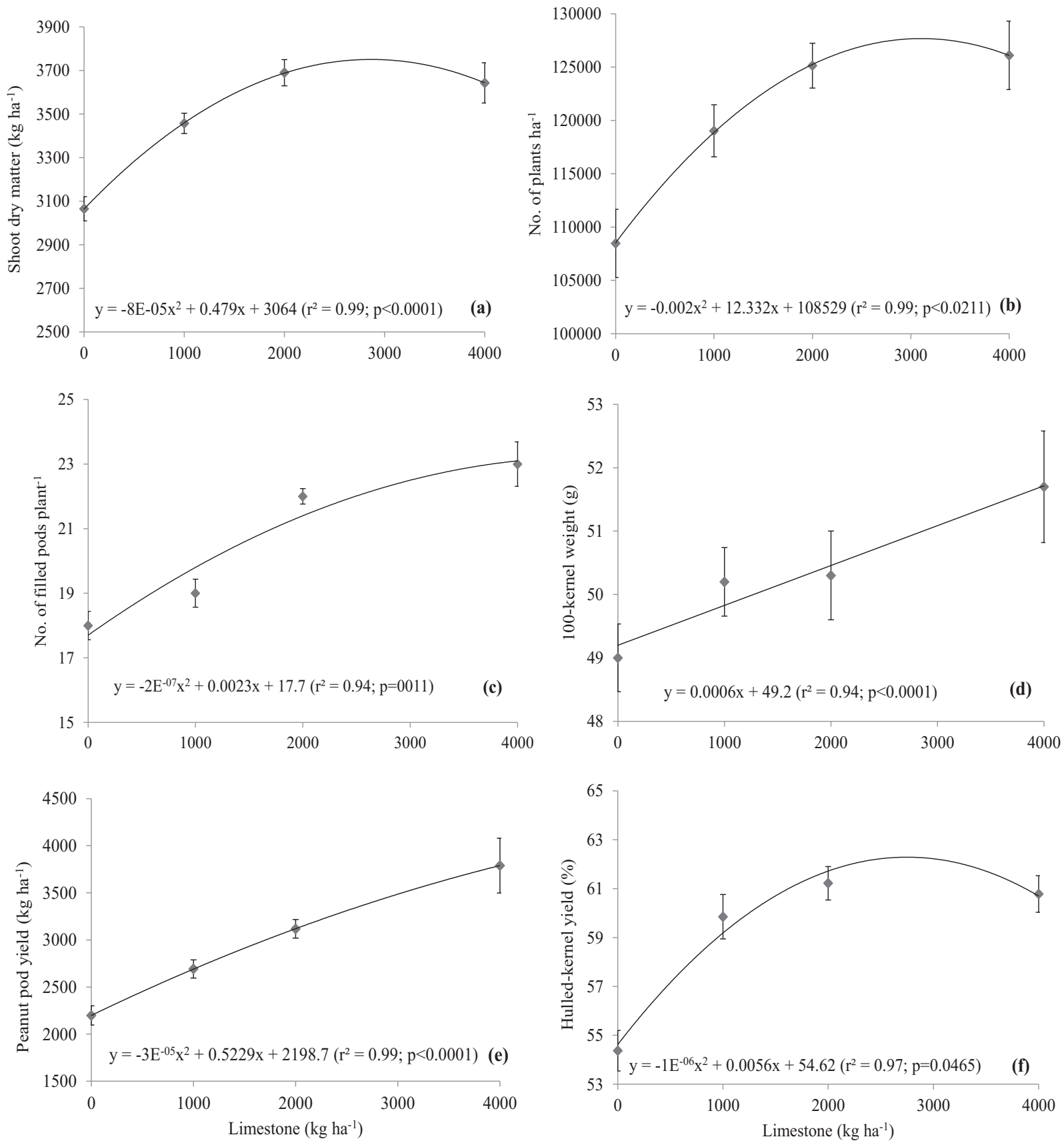

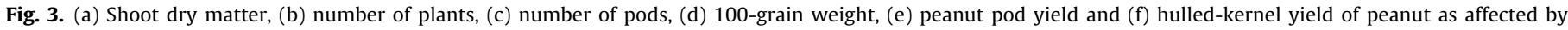
surface-applied dolomitic limestone rates in a long-term no-till soil. Bars indicate the standard error at each lime rate ( $\mathrm{n}=8$; four replicates $\times$ two growing seasons).

ity and potential and exchangeable values (Table 2). This result demonstrates the effectiveness of superficial liming in improving the chemical properties of highly acidic subsoils within a short time. Notably, even with a high base concentration in the top $0-0.05 \mathrm{~m}$, under the highest applied dose $\left(4.0 \mathrm{Mg} \mathrm{ha}^{-1}\right)$, the increase of the soil $\mathrm{pH}$ at 12 months was not excessive enough to harm the development of agricultural crops. According to Alleoni et al. (2005), this may be explained by the high buffering capacity existing in this layer, due to the accumulation of organic matter at the soil surface.

It is important to emphasize that the absence of mechanical mobilization promotes benefits related to the maintenance of aggregates and channels formed by soil biological activity. The preservation of soil physical properties is an important factor in the percolation of limestone particles into the subsoil; i.e., NT favors mobilization of the carbonate and the lime reaction at depth (Corrêa et al., 2009; Castro et al., 2011; Briedis et al., 2012). In addition to the soil physical conditions, experimental results have emphasized the importance of soil anions on $\mathrm{Ca}^{2+}$ and $\mathrm{Mg}^{2+}$ mobility into the subsoil.

After 24 months, liming decreased total and exchangeable acidity but it did not increased $\mathrm{pH}$ (Table 2). At 24 months, the effect of liming decreasing potential and exchangeable $\left(\mathrm{Al}^{3+}\right)$ acidity in the $0.40-0.60 \mathrm{~m}$ and $0.20-0.40$ depths was probably related to the action of water-soluble acids derived from the decomposition of the roots of previous crops, which can interfere with exchangeable and potential acidity by reducing the activity of $\mathrm{Al}^{3+}$ (Miyazawa et al., 2002; Soratto and Crusciol, 2007). Caires et al. (2000) found that potential acidity was reduced for up to approximately 28 months after superficial liming; however, the $\mathrm{pH}$ began to show decreases 

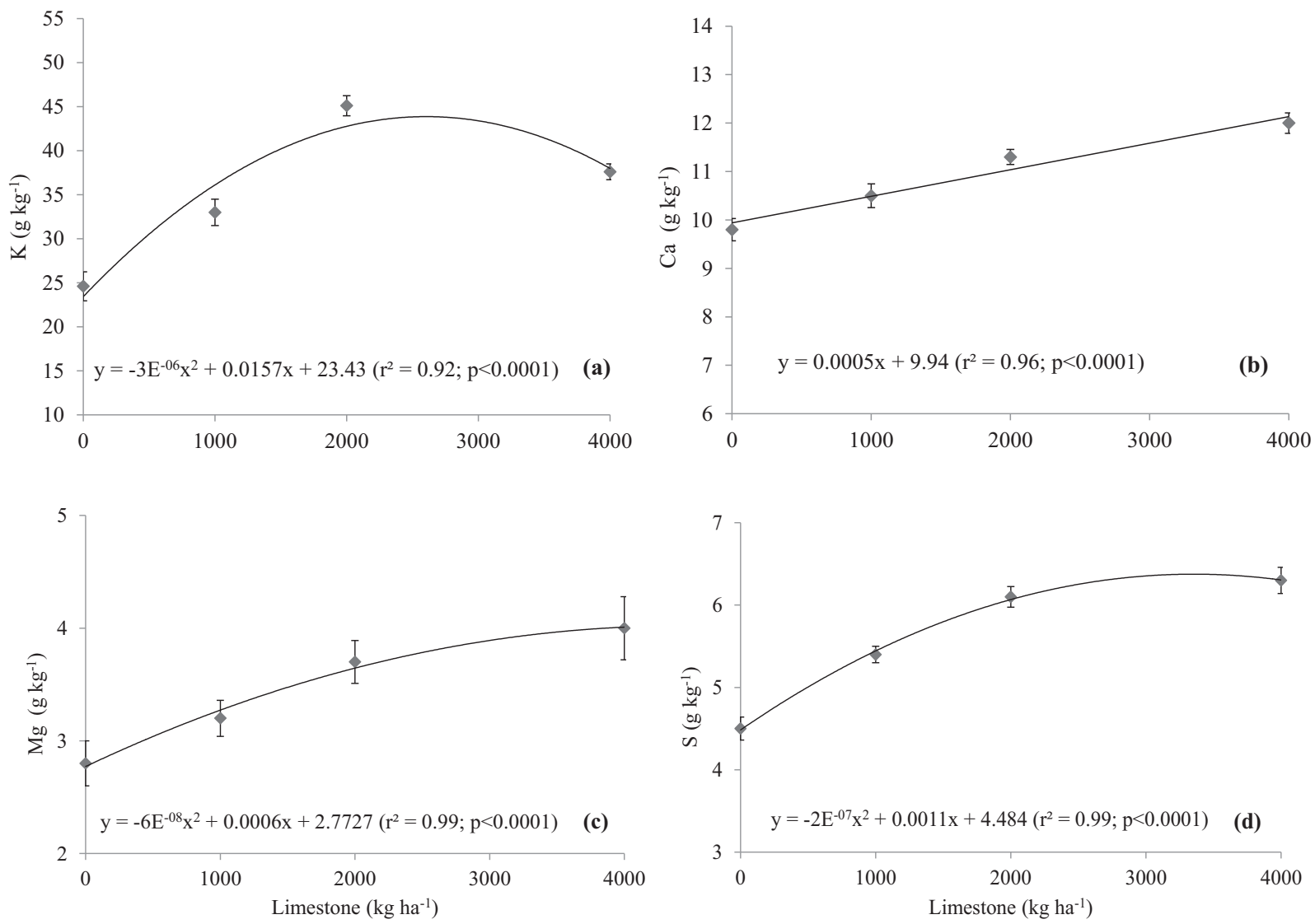

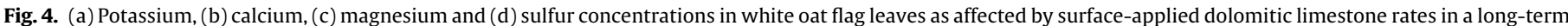
no-till soil. Bars indicate the standard error at each lime rate $(n=8$; four replicates $\times$ two growing seasons).

Table 4

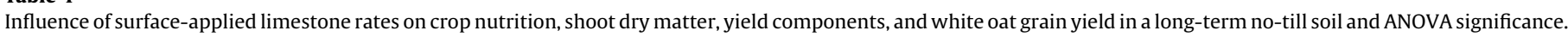

\begin{tabular}{|c|c|c|c|c|c|c|c|}
\hline Growing season & $\begin{array}{l}\mathrm{N} \\
\mathrm{g} \mathrm{kg}^{-1}\end{array}$ & $\mathrm{P}$ & K & $\mathrm{Ca}$ & $\mathrm{Mg}$ & $\mathrm{S}$ & $\begin{array}{l}\text { Shoot dry matter } \\
\mathrm{kg} \mathrm{ha}^{-1}\end{array}$ \\
\hline 2005 & $37.4 \mathrm{a}^{1}$ & $3.5 \mathrm{~b}$ & $29.8 \mathrm{~b}$ & $10.1 \mathrm{~b}$ & $2.6 \mathrm{~b}$ & $5.6 \mathrm{a}$ & $5574 \mathrm{a}$ \\
\hline 2006 & $34.5 \mathrm{~b}$ & $4.9 \mathrm{a}$ & $40.4 \mathrm{a}$ & $11.7 \mathrm{a}$ & $4.3 \mathrm{a}$ & $5.6 \mathrm{a}$ & $5011 \mathrm{~b}$ \\
\hline \multicolumn{8}{|l|}{ ANOVA (F probability) } \\
\hline Blocks & 0.5462 & 0.7241 & 0.6611 & 0.2412 & 0.1960 & 0.1209 & 0.1082 \\
\hline Limestone rates $(\mathrm{R})$ & 0.6083 & 0.2619 & $<0.0001$ & 0.0006 & 0.0288 & $<0.0001$ & 0.0002 \\
\hline Growing season (S) & 0.0450 & $<0.0001$ & $<0.0001$ & $<0.0001$ & $<0.0001$ & 0.9354 & 0.0001 \\
\hline $\mathrm{R} \times \mathrm{S}$ & 0.9891 & 0.8000 & 0.4311 & 0.7977 & 0.8291 & 0.5531 & 0.9928 \\
\hline Growing season & \multicolumn{2}{|c|}{$\begin{array}{l}\text { Panicles per square meter } \\
n^{\circ}\end{array}$} & \multicolumn{2}{|c|}{$\begin{array}{l}\text { Spikelet per panicles } \\
n^{\circ}\end{array}$} & $\begin{array}{l}\text { Spikelet fertility } \\
\%\end{array}$ & $\begin{array}{l}\text { 1000-grain weight } \\
\mathrm{g}\end{array}$ & $\begin{array}{l}\text { Grain yield } \\
\mathrm{kg} \text { ha-1 }\end{array}$ \\
\hline 2005 & \multicolumn{2}{|l|}{$296 b^{1}$} & \multicolumn{2}{|l|}{$37 \mathrm{~b}$} & $95 \mathrm{a}$ & $21.3 \mathrm{a}$ & 2197 b \\
\hline 2006 & \multicolumn{2}{|l|}{336 a } & 52 a & & $94 \mathrm{a}$ & $20.4 \mathrm{a}$ & 3292 a \\
\hline \multicolumn{8}{|l|}{ ANOVA (F probability) } \\
\hline Blocks & \multicolumn{2}{|c|}{0.1264} & \multicolumn{2}{|l|}{0.7143} & 0.7789 & 0.2137 & 0.3943 \\
\hline Limestone rates ( $\mathrm{R}$ ) & \multicolumn{2}{|c|}{0.0024} & \multicolumn{2}{|l|}{0.0470} & 0.0865 & 0.1210 & 0.0002 \\
\hline Growing season $(\mathrm{S})$ & \multicolumn{2}{|l|}{0.0010} & \multicolumn{2}{|l|}{$<0.0001$} & 0.6527 & 0.0641 & $<0.0001$ \\
\hline $\mathrm{R} \times \mathrm{S}$ & \multicolumn{2}{|l|}{0.6818} & \multicolumn{2}{|l|}{0.7879} & 0.8995 & 0.3671 & 0.3604 \\
\hline
\end{tabular}

${ }^{1}$ Means followed by different letters in the column differ statistically by the LSD test $(\mathrm{p}<0.05)$.

from 12 months onwards. Thus, there is not always an inverse relationship between potential acidity and $\mathrm{pH}$.

Due to the mineralogical attributes of Oxisols, phosphate is strongly adsorbed on Al- and Fe-(oxy) hydroxide surfaces, irrespective of the nature of the charges. However, the effect of the lime reaction on increasing phosphorus availability (Table 2) can be attributed to the competitive adsorption between $\mathrm{OH}^{-}$and phosphate for the same site, resulting in lower $\mathrm{P}$ adsorption by oxides (Sato and Comerford, 2005). In addition, Haynes (1984) reported that the anion repulsion effect by increasing negative charges on oxides could also contribute to P bioavailability. The influence of liming on the availability of phosphorus in acid soils has also been reported by other researchers (Haynes, 1982; Jaskulska et al., 2014); however, the increased availability in the subsurface layers is notable because phosphorus generally shows limited mobility in soil, and increasing its availability contributes greatly to increasing its interception and absorption by plant roots. 
Table 5

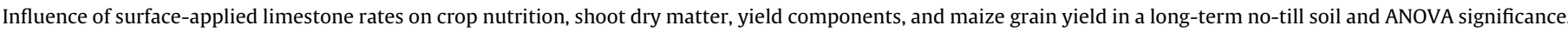

\begin{tabular}{|c|c|c|c|c|c|c|c|}
\hline Growing season & $\begin{array}{l}\mathrm{N} \\
\mathrm{g} \mathrm{kg}^{-1}\end{array}$ & $\mathrm{P}$ & K & $\mathrm{Ca}$ & $\mathrm{Mg}$ & $\mathrm{S}$ & $\begin{array}{l}\text { Shoot dry matter } \\
\mathrm{kg} \mathrm{ha}^{-1}\end{array}$ \\
\hline $2006 / 2007$ & $28 b^{1}$ & $2.3 \mathrm{~b}$ & $24 \mathrm{~b}$ & $3.5 \mathrm{~b}$ & $2.9 \mathrm{~b}$ & $1.7 \mathrm{~b}$ & $14235 \mathrm{~b}$ \\
\hline $2007 / 2008$ & $32 \mathrm{a}$ & $2.5 \mathrm{a}$ & $27 \mathrm{a}$ & $3.8 \mathrm{a}$ & $2.0 \mathrm{a}$ & $1.9 \mathrm{a}$ & $20174 \mathrm{a}$ \\
\hline \multicolumn{8}{|c|}{ ANOVA (F probability) } \\
\hline Blocks & 0.4528 & 0.2610 & 0.7628 & 0.6299 & 0.3422 & 0.6890 & 0.3432 \\
\hline Limestone rates $(\mathrm{R})$ & $<0.0001$ & 0.8208 & $<0.0001$ & $<0.0001$ & $<0.0001$ & $<0.0001$ & $<0.0001$ \\
\hline Growing season (S) & $<0.0001$ & 0.0137 & $<0.0001$ & $<0.0001$ & $<0.0001$ & $<0.0001$ & $<0.0001$ \\
\hline $\mathrm{R} \times \mathrm{S}$ & 0.4632 & 0.9999 & 0.7264 & 0.1230 & 0.6977 & 0.4298 & 0.6815 \\
\hline Growing season & \multicolumn{2}{|c|}{$\begin{array}{l}\text { Final population } \\
\mathrm{n}^{\circ}\end{array}$} & $\begin{array}{l}\text { Ear per plant } \\
\mathrm{n}^{\circ}\end{array}$ & \multicolumn{2}{|c|}{$\begin{array}{l}\text { Grains per ear } \\
\mathrm{n}^{\circ}\end{array}$} & $\begin{array}{l}\text { 100-grain weight } \\
\mathrm{g}\end{array}$ & $\begin{array}{l}\text { Grain yield } \\
\mathrm{kg} \mathrm{ha}^{-1}\end{array}$ \\
\hline $2006 / 2007$ & \multicolumn{2}{|c|}{$63350 a^{1}$} & $0.80 \mathrm{~b}$ & \multicolumn{2}{|l|}{$348 \mathrm{~b}$} & $36 \mathrm{~b}$ & $6090 \mathrm{~b}$ \\
\hline $2007 / 2008$ & \multicolumn{2}{|c|}{$60332 \mathrm{~b}$} & $0.84 \mathrm{a}$ & \multicolumn{2}{|l|}{$435 \mathrm{a}$} & $40 \mathrm{a}$ & $8632 \mathrm{a}$ \\
\hline \multicolumn{8}{|l|}{ ANOVA (F probability) } \\
\hline Blocks & \multicolumn{2}{|c|}{0.2683} & 0.3282 & \multicolumn{2}{|l|}{0.3318} & 0.1170 & 0.1152 \\
\hline Limestone rates $(\mathrm{R})$ & \multicolumn{2}{|c|}{$<0.0001$} & 0.0711 & \multicolumn{2}{|l|}{$<0.0001$} & 0.5514 & $<0.0001$ \\
\hline Growing season (S) & \multicolumn{2}{|c|}{$<0.0001$} & $<0.0001$ & \multicolumn{2}{|l|}{$<0.0001$} & 0.0019 & $<0.0001$ \\
\hline $\mathrm{R} \times \mathrm{S}$ & \multicolumn{2}{|c|}{0.3629} & 0.9999 & \multicolumn{2}{|l|}{0.0808} & 0.9999 & 0.4551 \\
\hline
\end{tabular}

${ }^{1}$ Means followed by different letters in the column differ statistically by the LSD test $(\mathrm{p}<0.05)$.

Table 6

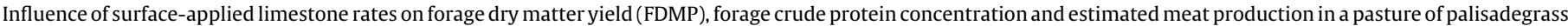
in a long-term no-till soil and ANOVA significance.

\begin{tabular}{|c|c|c|c|c|c|c|c|}
\hline & \multicolumn{2}{|c|}{$\operatorname{FDMP}\left(\mathrm{kg} \mathrm{ha}^{-1}\right)$} & \multicolumn{2}{|c|}{ Crude protein (\%) } & \multicolumn{3}{|c|}{ Estimated meat production $\left(\mathrm{kg} \mathrm{ha}^{-1}\right)^{\alpha}$} \\
\hline & First cut ${ }^{2}$ & Second cut ${ }^{2}$ & First cut ${ }^{2}$ & Second cut ${ }^{2}$ & First cut ${ }^{2}$ & Second cut ${ }^{2}$ & Total \\
\hline \multicolumn{8}{|l|}{ Growing season } \\
\hline 2007 & $4127 b^{1}$ & 4986 b & $11.0 \mathrm{a}$ & $10.3 \mathrm{a}$ & $199.0 \mathrm{~b}$ & $225.1 \mathrm{~b}$ & $424.1 \mathrm{~b}$ \\
\hline 2008 & $5447 \mathrm{a}$ & $6581 \mathrm{a}$ & $10.8 \mathrm{~b}$ & $10.1 \mathrm{~b}$ & $266.5 \mathrm{a}$ & 298.9 a & $565.4 \mathrm{a}$ \\
\hline \multicolumn{8}{|c|}{ ANOVA (F probability) } \\
\hline Blocks & 0.8675 & 0.6870 & 0.9745 & 0.5891 & 0.4025 & 0.6201 & 0.7001 \\
\hline Limestone rates $(\mathrm{R})$ & $<0.0001$ & $<0.0001$ & $<0.0001$ & $<0.0001$ & $<0.0001$ & $<0.0001$ & $<0.0001$ \\
\hline Growing season (S) & $<0.0001$ & $<0.0001$ & 0.0037 & 0.0440 & $<0.0001$ & $<0.0001$ & $<0.0001$ \\
\hline $\mathrm{R} \times \mathrm{S}$ & 0.0281 & 0.0242 & 0.9921 & 0.9858 & 0.0059 & 0.0002 & $<0.0001$ \\
\hline
\end{tabular}

${ }^{\alpha}$ Estimated meat production $=\mathrm{kg}$ of body weight gain (cattle) per ha (estimated) $\times 52 \%$ of carcass yield.

1 Means followed by different letters in the column differ statistically by the LSD test $(\mathrm{p}<0.05)$.

2 First and second cuts in June and August, respectively.

Table 7

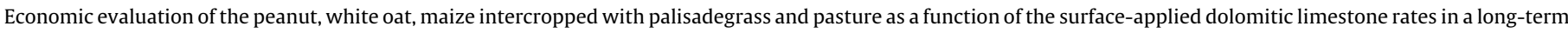
no-till soil.

\begin{tabular}{|c|c|c|c|c|c|c|c|c|c|c|}
\hline Limestone rates $\left(\mathrm{kg} \mathrm{ha}^{-1}\right)$ & $\begin{array}{l}\text { Peanut } \\
2004 / 2005\end{array}$ & $\begin{array}{l}\text { White oat } \\
2005\end{array}$ & $\begin{array}{l}\text { Peanut } \\
2005 / 2006\end{array}$ & $\begin{array}{l}\text { White oat } \\
2006\end{array}$ & $\begin{array}{l}\text { Maize } \\
2006 / 2007\end{array}$ & $\begin{array}{l}\text { Pasture (meat) } \\
2007\end{array}$ & $\begin{array}{l}\text { Maize } \\
2007 / 2008\end{array}$ & $\begin{array}{l}\text { Pasture (meat) } \\
2008\end{array}$ & $\begin{array}{l}\text { Total }^{4} \\
-\end{array}$ & $\begin{array}{l}\operatorname{Mean}^{5} \\
-\end{array}$ \\
\hline \multicolumn{11}{|l|}{$\operatorname{Cost}^{1}\left(€ \mathrm{ha}^{-1}\right)$} \\
\hline 0 & 726 & 206 & 726 & 206 & 576 & 131 & 576 & 131 & 3278 & 820 \\
\hline 1000 & 752 & 206 & 726 & 206 & 576 & 212 & 576 & 215 & 3470 & 868 \\
\hline 2000 & 779 & 206 & 726 & 206 & 576 & 328 & 576 & 344 & 3741 & 935 \\
\hline 4000 & 832 & 206 & 726 & 206 & 576 & 288 & 576 & 300 & 3709 & 927 \\
\hline \multicolumn{11}{|l|}{ Revenue $^{2}\left(€\right.$ ha $\left.^{-1}\right)$} \\
\hline 0 & 513 & 137 & 709 & 205 & 708 & 518 & 1018 & 669 & 4476 & 1119 \\
\hline 1000 & 628 & 181 & 868 & 271 & 784 & 838 & 1127 & 1098 & 5794 & 1449 \\
\hline 2000 & 728 & 233 & 1005 & 349 & 1002 & 1295 & 1442 & 1752 & 7805 & 1951 \\
\hline 4000 & 885 & 176 & 1222 & 265 & 925 & 1135 & 1331 & 1528 & 7465 & 1866 \\
\hline \multicolumn{11}{|l|}{ Net profit ${ }^{3}\left(€\right.$ ha $\left.^{-1}\right)$} \\
\hline 0 & -213 & -69 & -17 & -1 & 131 & 386 & 442 & 538 & 1198 & 299 \\
\hline 1000 & -124 & -25 & 142 & 65 & 207 & 625 & 551 & 882 & 2324 & 581 \\
\hline 2000 & -51 & 27 & 279 & 143 & 426 & 967 & 866 & 1408 & 4064 & 1016 \\
\hline 4000 & 53 & -30 & 496 & 59 & 349 & 847 & 755 & 1228 & 3756 & 939 \\
\hline
\end{tabular}

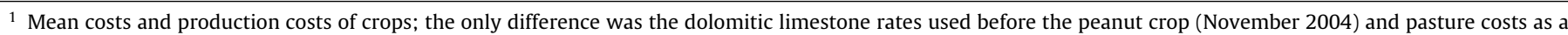
function of the animal stocking rate.

2 Revenue $=\mathrm{kg}$ of peanut, white oat and maize grain yields and estimated meat production per ha $\times € 0.28$, $€ 0.08$, $€ 0.14$ and $€ 2.23$, respectively

3 Net profit is the realization per ha, which was calculated using the following formula: revenue - cost.

4 Total = sum of all growing seasons.

${ }^{5}$ Mean $=$ mean by growing season. 

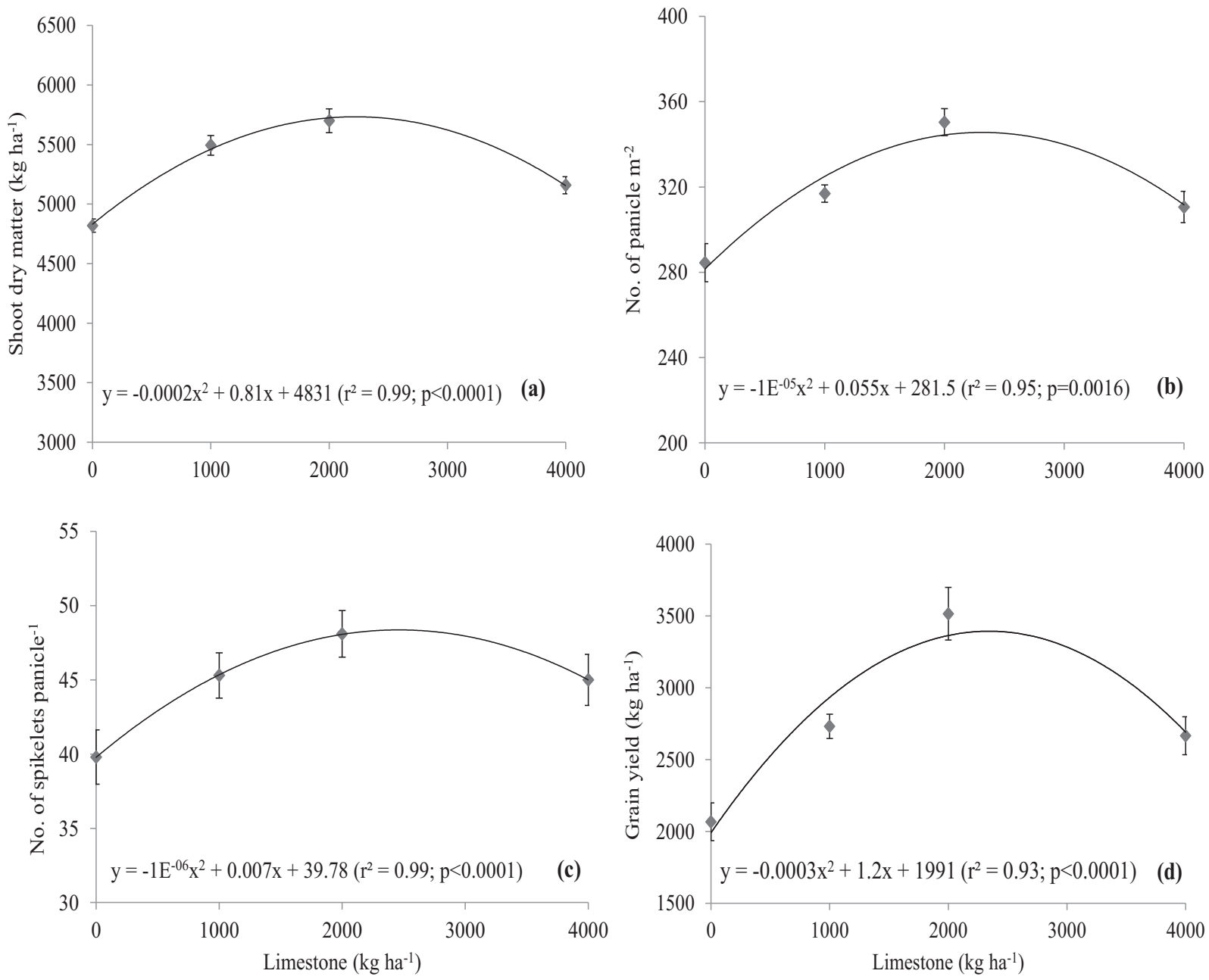

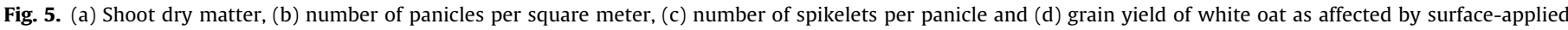
dolomitic limestone rates in a long-term no-till soil. Bars indicate the standard error at each lime rate ( $\mathrm{n}=8$; four replicates $\times$ two growing seasons).

The K levels increased in the upper soil layers $(0-0.05,0.05-0.10$ and $0.10-0.20 \mathrm{~m}$ ) with liming after 12 months (Table 2). This increase can be explained by the increase in the soil $\mathrm{pH}$, which enhanced $\mathrm{K}$ adsorption capacity by the soil, reduced $\mathrm{K}$ losses through leaching, and improved the $\mathrm{K}$ fertilizer efficiency (Krause, 1965). In a relatively short period, this effect was not observed in the deeper layers, possibly due to the lower lime mobility; however, after 24 months, liming increased $\mathrm{K}$ availability in all soil profiles, likely in response to an enhanced sorptive complex.

Regarding the increases in $\mathrm{Ca}^{2+}$ and $\mathrm{Mg}^{2+}$ availability (Table 2) observed in all layers after 12 months, it should be considered that limestone is a major source for the replacement of these nutrients in the soil. Several researchers have reported the fundamental role of this corrective process as an important $\mathrm{Ca}^{2+}$ and $\mathrm{Mg}^{2+}$ complement in cropping systems (Caires et al., 2005, 2008a,b, 2015; Soratto and Crusciol, 2008a; Fageria et al., 2010; Castro and Crusciol, 2013b). However, the present study emphasizes the increase in the levels of these nutrients in the subsoil, with significant increases observed down to a depth of $0.60 \mathrm{~m}$. The displacement of exchangeable cations in the soil profile may be related to the formation of stable complexes between $\mathrm{Ca}^{2+}$ and $\mathrm{Mg}^{2+}$ and soluble organic compounds (Franchini et al., 1999), although this mechanism is not common, and to the presence and quantity of porous channels that allow the movement of limestone downward through water displacement (Amaral et al., 2004).
We highlight that after 24 months, there was a small increase in $\mathrm{Ca}^{2+}$ levels compared to the first sampling (12 months). This phenomenon was most likely related to the reaction of some portion of the applied limestone in the period between samplings. Furthermore, the low nutrient export by the grains may have contributed to this increase. The increase in base saturation in all of the evaluated layers was the effect of the reduction in acidity and the increased Ca and Mg levels, as evidenced by Ciotta et al. (2004).

\subsection{Peanut, white oat, and maize nutrition}

The highest $\mathrm{N}$ concentrations observed in the peanut and maize leaves (Figs. 2a and 6a) were probably related to the effects of liming on soil nitrate availability, as nitrate is one of the main forms of $\mathrm{N}$ absorbed by plants. The availability of nitrate may increase with an increasing $\mathrm{pH}$ due to liming because nitrification activity is lower at acidic pH (Islam et al., 2006) and explains the increased nitrate concentration observed in soils with acidity correction (Silva and Vale, 2000).

Observed $\mathrm{N}$ concentration in maize was within the range considered adequate for peanuts and maize (Ambrosano et al., 1997; Cantarella et al., 1997), independent of the lime rate applied. In the white oat crop, $\mathrm{N}$ concentrations were not influenced by liming (Table 3), but the $\mathrm{N}$ concentration was above that considered adequate (Cantarella et al., 1997). 

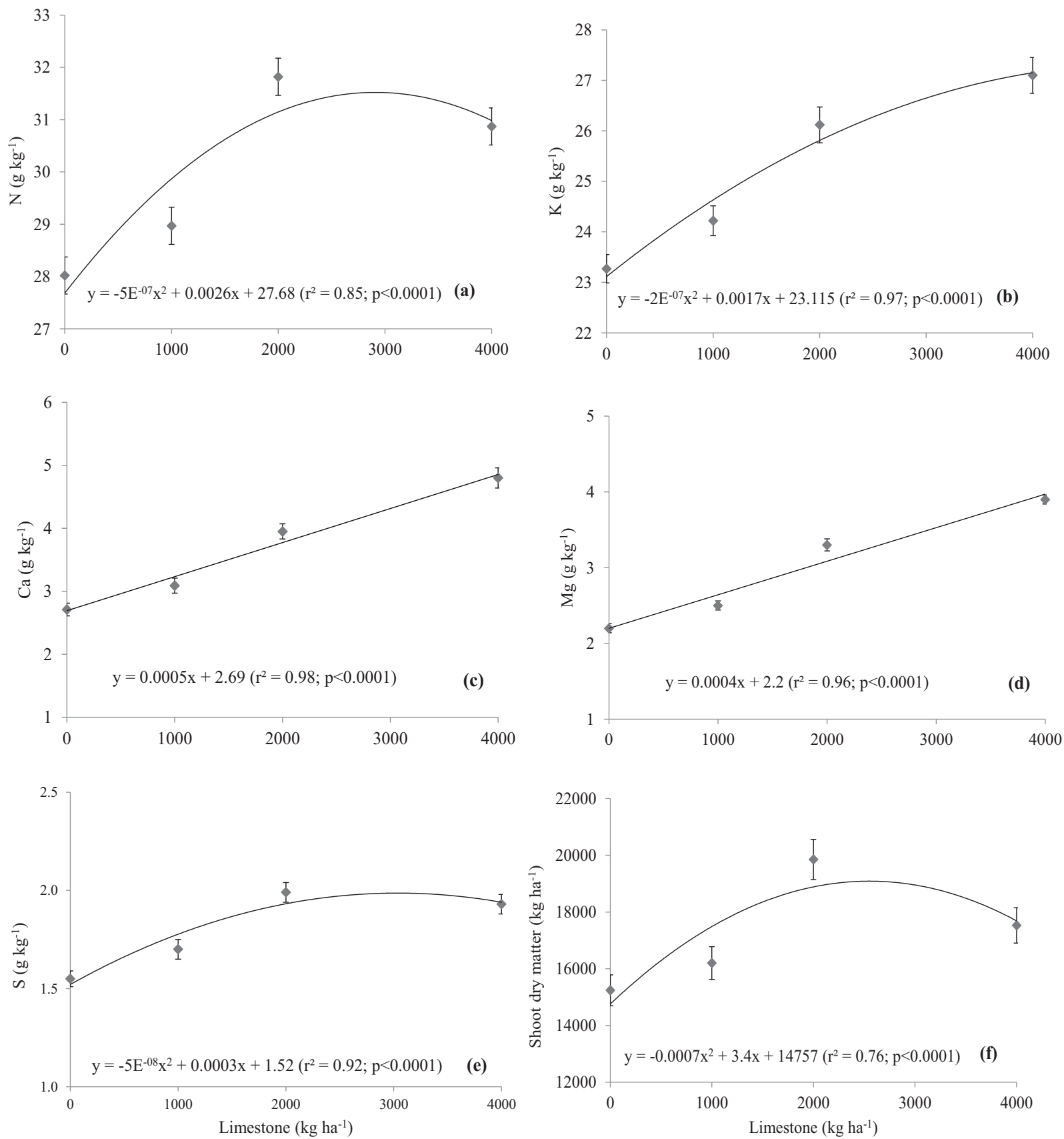

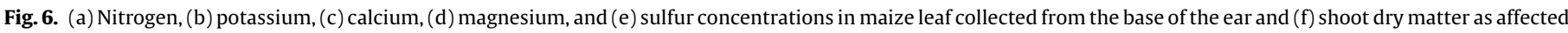
by surface-applied dolomitic limestone rates in a long-term no-till soil. Bars indicate the standard error at each lime rate ( $\mathrm{n}=8$; four replicates $\times$ two growing seasons).

The P concentration was affected by liming only in the peanut crop (Fig. 2b); this effect may be related to the lower P adsorbed by Fe- and Al-(oxy) hydroxides. In other words, the recent lime application increased P bioavailability in the upper soil layers, increasing P utilization by peanut plants grown after application. In addition, the improved chemical conditions due to liming may have favored the root architecture, increasing plants' ability to extract $P$ from soil. Considering these aspects, it was notable that the highest $\mathrm{P}$ concentration in peanut leaves was observed in the second growing season (Table 3), and this value was considered to be above the critical range proposed by Ambrosano et al. (1997). In the other crops, despite the increase in soil P bioavailability due to limestone application, the $P$ concentrations in plants remained unaffected (Tables 4 and 5). However, it is important to note that the P con- centrations in white oat and maize leaves were within the range that is considered sufficient (Cantarella et al., 1997).

The increases in $\mathrm{K}, \mathrm{Ca}, \mathrm{Mg}$ and $\mathrm{S}$ levels observed in peanut (Fig. 2c-f), white oat (Fig. 4a-d) and maize (Fig. 6b-e) leaves as a function of liming were related to the greater availability of these macronutrients in the soil (Table 2). The benefits of liming to shoot dry matter production (peanuts, white oat and maize) (Figs. 3a, 5a, and $6 \mathrm{f}$, respectively) reflect improved soil chemical characteristics (Table 2). The increased shoot growth probably resulted from better root development, which increased the absorption capacity of nutrients and water. Caires et al. (2006b) confirmed the existence of a correlation between wheat (Triticum spp.) root growth and soil chemical properties, mainly regarding an increased $\mathrm{pH}$, increased $\mathrm{Ca}^{2+}$ availability, increased base saturation, and reduced $\mathrm{Al}^{3+}$. 

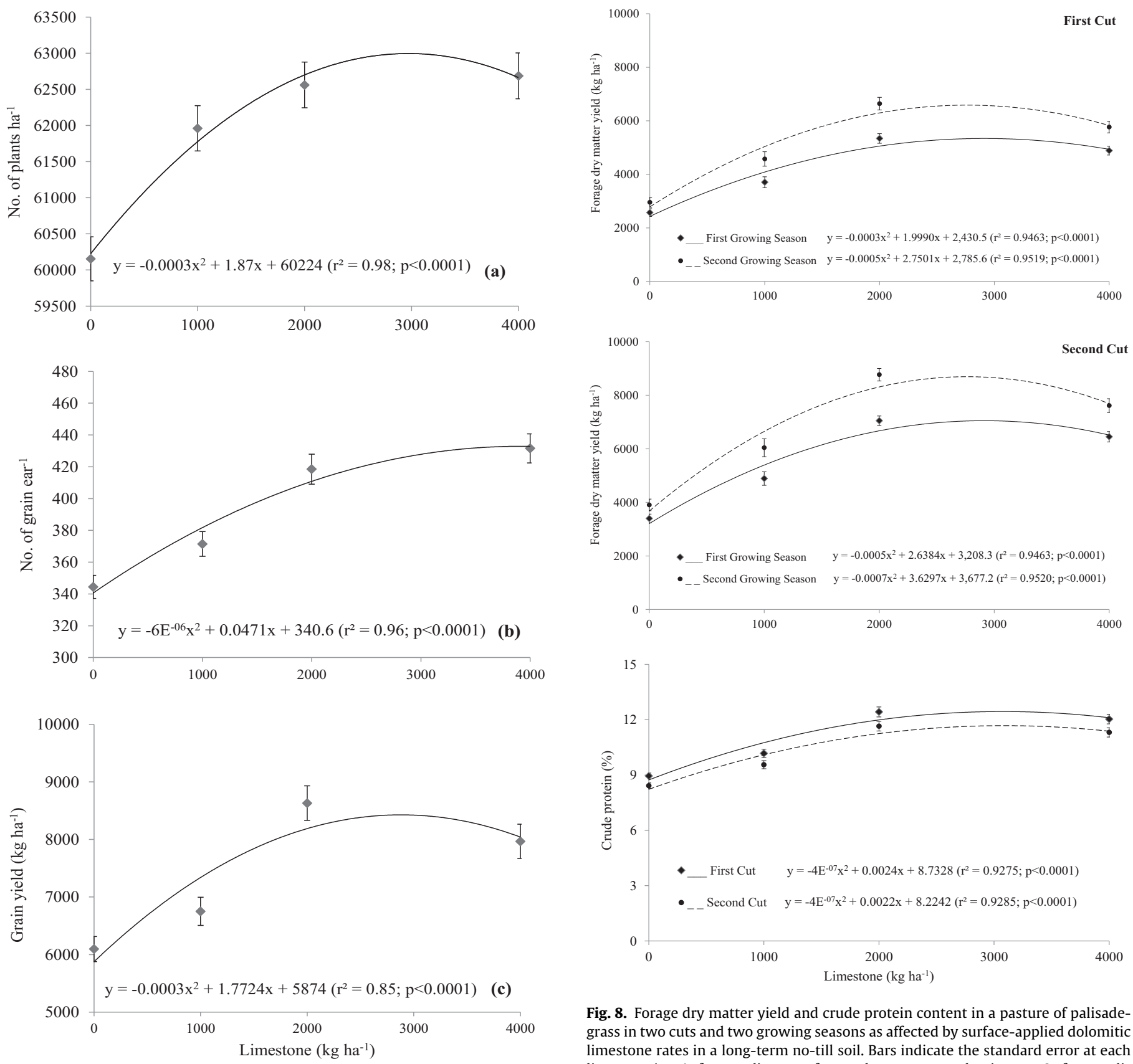

Fig. 8. Forage dry matter yield and crude protein content in a pasture of palisadegrass in two cuts and two growing seasons as affected by surface-applied dolomitic limestone rates in a long-term no-till soil. Bars indicate the standard error at each lime rate $(n=4$; four replicates - forage dry matter production; $n=8$; four replicates $\times$ two growing seasons - crude protein).

Fig. 7. (a) Number of plants per area, (b) number of grains per ear, and (c) grain yield of maize as affected by surface-applied dolomitic limestone rates in a long-term notill soil. Bars indicate the standard error at each lime rate $(n=8$; four replicates $\times$ two growing seasons).

\subsection{Peanut, white oat, and maize components and kernel/grain yields}

The positive results of surface liming on yield components and the kernel/grain yield (peanuts, white oat and maize) (Figs. 3, 5, and 7) were the result of reduced acidity and increased soil nutrient availability (Table 2). These results are in accordance with those observed by Caires et al. (2000), who reported correlations between cumulative grain production and soil chemical properties, especially regarding increases in $\mathrm{pH}$, exchangeable $\mathrm{Ca}^{2+}$, and base saturation as well as reductions in exchangeable $\mathrm{Al}^{3+}$.

The increase in white oat grain yields observed after liming (Fig. 5d) was similar to the results presented by Castro and Crusciol (2013b), who reported positive effects on white oat yield compo-

nents due to reduced acidity and also minimizes the harmful effects of acidity on crop development and thereby increases the number of panicles per area and the number of spikelets per panicle, with significant effects on the grain yield.

As observed for the other species, the significant increases in the maize yield are justified by the chemical changes brought about by liming (Table 2). Castro and Crusciol (2013a,b) also demonstrated the benefits of these changes on the yield components responsible for determining the grain yield. According to Caires et al. (2000), the morphological parameters of maize roots are modified by superficial lime application in NT. These authors observed a reduction in the relative root length in the soil surface layer $(0-0.10 \mathrm{~m})$ and an increase in the subsoil $(0.20-0.60 \mathrm{~m})$ as a function of increasing doses of liming. In other words, in higher-acidity conditions, the maize root system is restricted to the surface, which makes plants vulnerable to water deficits. Similar effects may have occurred dur- 

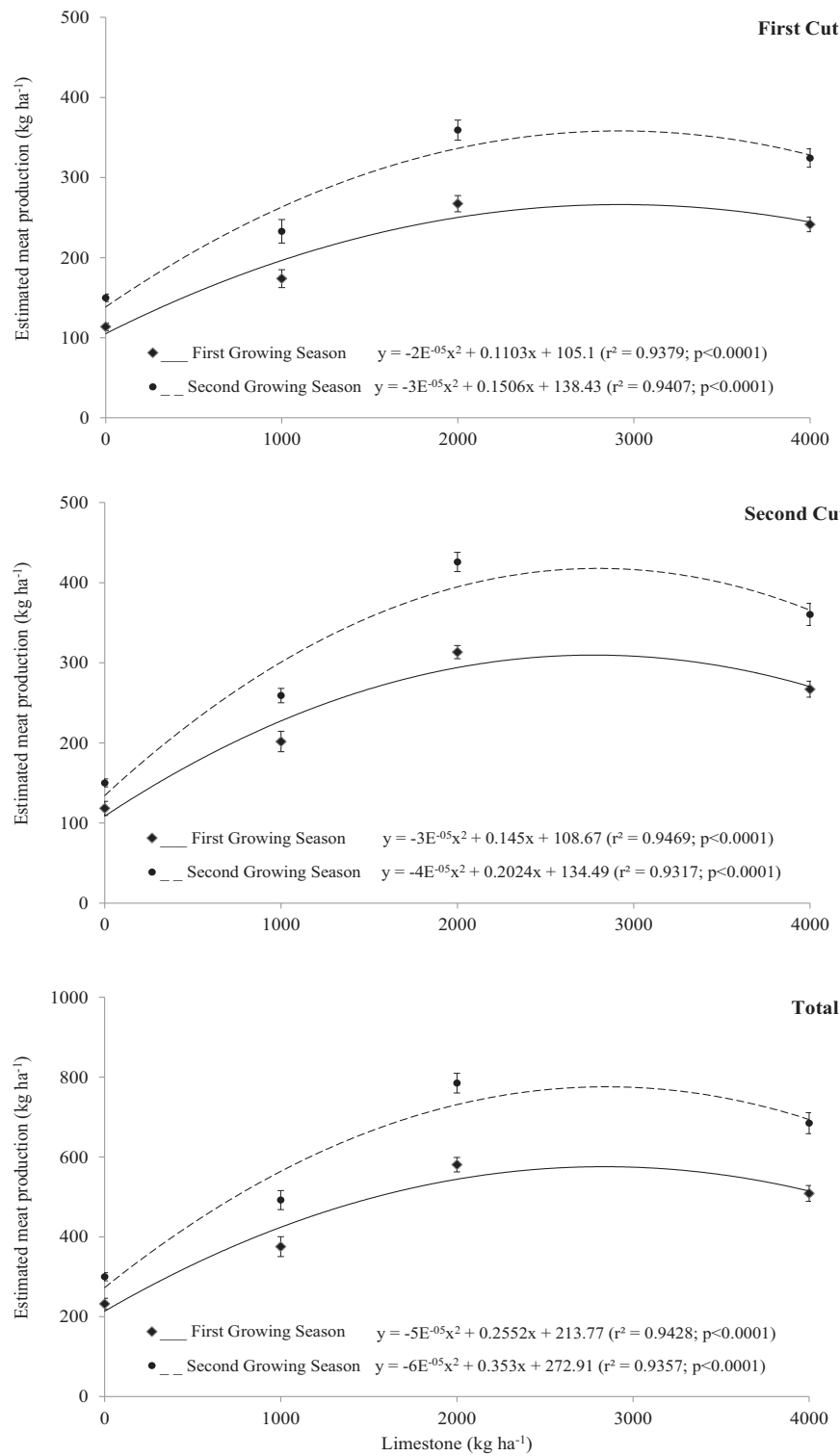

Fig. 9. Estimated meat production in a pasture of palisade grass in two cuts and total in two growing seasons as affected by surface-applied dolomitic limestone rates in a long-term no-till soil. Bars indicate the standard error at each lime rate $(n=4$; four replicates).

ing maize development because dry spells occurred in February 2007 and 2008 (Fig. 1c and d).

However, attention should be paid to the use of higher doses of lime, which caused reductions in white oat and maize grain yields in this study (Figs. 5d and 7c). These results are similar to those reported by Caires et al. (2000) and Soratto and Crusciol (2008b), who attributed this effect to the lower availability of some micronutrients, especially cationic micronutrients, whose solubility decreases with an increasing $\mathrm{pH}$. We note that the lime rates estimated to achieve the maximum grain yield, especially in white oat and maize, were very close to those calculated to adjust the base saturation of a soil sample collected at the $0-0.20 \mathrm{~m}$ depth to $70 \%$, indicating that this surface liming recommendation is effective for the studied tropical no-till soil.

The higher kernel/grain yield (peanut, white oat and maize) observed in the second growing season (Tables 3-5) may have resulted from soil and weather conditions during the plants' development, which greatly affected crop productivity (Fig. 1).

\subsection{Forage characteristics and estimated meat production}

The forage dry matter yield and estimated meat production were highest in the second growing season (2008) compared to the first growing season (2007) (Table 6 and Fig. 8); as a function of the stimulus from tilling after the first cut, the forage dry matter yield was higher during the second cut in both growing seasons. The low temperatures and low rainfall, mainly during August and September in the first growing season (2007), contributed to the lower forage dry matter yield. According to Costa et al. (2005), the optimal temperature range for palisade grass development was between 30 and $35^{\circ} \mathrm{C}$, and its growth was greatly reduced between 10 and $15^{\circ} \mathrm{C}$. In addition, Costa et al. (2005) reported that low rainfall, which is characteristic of regions with dry winters, such as the Brazilian Cerrado during June and July, is another cause of the reduced palisade grass development observed in our trial for the first cutting. The observed two-year-average crude protein concentration of approximately $8.2-12.5 \%$ is higher than the crude protein of $7 \%$ reported by van Soest (1994) as the minimum concentration required for maintaining microbial populations in the rumen of cattle.

The forage dry matter yield (2573-6642 $\mathrm{kg} \mathrm{ha}^{-1}$ in the first cut and $3397-8767 \mathrm{~kg} \mathrm{ha}^{-1}$ in the second cut) in this study (Table 6; Fig. 8) can be considered high during this season (winter/spring). The forage dry matter yield can be used as an index for mechanical cutting or in the fields for grazing by animals (Pariz et al., 2011b) and to increase the estimated meat production (Fig. 9) and revenue of the farmer. Typically, during this time of the year (June to September), the availability of forage in areas with dry winters is limited (Borghi et al., 2013). Sowing tropical forage after a maize grain harvest does not provide sufficient fodder during the autumn, winter and part of the spring in regions with dry winters, such as the Brazilian Cerrado or African Savanna. However, in this intercropping system, the rain that falls after the maize is harvested (in April and May) allows for adequate development of palisade grass.

The forage dry matter yield, crude protein concentrations and estimated meat production increased quadratically as a function of the lime rate (Figs. 8 and 9). This result indicates that when low rates of surface limestone are used for maize intercropped with palisade grass, the forage dry matter yield is also low in the winter/spring, consequently reducing the estimated meat production. In the subtropical Brazilian regions, the surface limestone (application or reapplication) in an integrated crop-livestock system (soybeanbeef cattle) also increased the forage dry matter yield [mix of black oat + Italian ryegrass (Lolium multiflorum)] and reduced the longterm soil acidification, with a higher base saturation and lower aluminum saturation, mainly in the grazed areas compared to the non-grazed areas (Martins et al., 2014a, 2014b, 2016).

\subsection{Economic evaluation}

The surface application of no dolomitic limestone resulted in a negative net profit for peanut and white oat in both growing seasons (Table 7). This result demonstrates the importance of the limestone practice in an annual crop rotation of tropical pastures under no-till. All treatments resulted in a positive total profit and a mean net profit, mainly using $2000 \mathrm{~kg} \mathrm{ha}^{-1}$ of limestone. An integrated crop-livestock system using maize intercropped with palisade grass is a good option in a tropical agricultural system because in addition to maize grain produce in summer/autumn, the farmers can use the forage dry matter yield of palisade grass (Table 6 and Fig. 8) for animal fodder in winter/spring. The pasture of palisade grass in winter/spring provided a higher net profit compared to white oat. Thus, $232-785 \mathrm{~kg}$ of meat per ha could be produced in both cuts (Fig. 9), with net profits of $€ 386-1408$ per ha, depending on the surface limestone rate applied-reapplied in the crop rotation (a rate of $2000 \mathrm{~kg} \mathrm{ha}^{-1}$ of limestone results in higher 
net profits, as a function of higher forage dry matter and estimated meat production).

Therefore, our data indicated that an annual crop rotation of a tropical pasture under no-till using maize intercropped with palisade grass is a promising option for farmers and liming can improve crop-livestock systems involving the crop rotation studied.

\section{Conclusions}

The surface application of limestone in a tropical no-till soil effectively reduced soil acidity from the surface down to a depth of $0.60 \mathrm{~m}$, resulting in greater availability of $\mathrm{P}$ and $\mathrm{K}$ near the soil surface. The Ca and Mg availability in the soil also increased with the limestone application rates up to a depth of $0.60 \mathrm{~m}$. Nutrient absorption was enhanced by liming, especially regarding the plant uptake of K, Ca and Mg. Significant increases in the yield components and kernel/grain yields of peanuts, white oat and maize were obtained with surface application of limestone. The lime rates estimated to achieve the maximum grain yield, especially in white oat and maize, were very close to the rates that are necessary to raise the base saturation of a soil sample collected at the $0-0.20 \mathrm{~m}$ depth to $70 \%$. This lime rate also increases the forage dry matter yield, the crude protein concentration and the estimated meat production during winter/spring in the maize-palisade grass intercropping, provides the highest total and mean net profit during the four growing seasons and can improve the long-term sustainability of tropical agriculture in the Brazilian Cerrado.

\section{Acknowledgements}

The authors would like to thank the São Paulo Research Foundation (FAPESP, grant \#2003/09914-3) and the Coordination for the Improvement of Higher Education Personnel (CAPES, PROAP - Program to Support Graduate) for financial support. In addition, the first and fourth authors would like to thank the National Council for Scientific and Technological Development (CNPq) for an award for excellence in research.

\section{References}

Agrolink, 2016. Quotations to Farming, Available at: www.agrolink.com.br (accessed 05.02.16.)

Alford, C.M., Krall, J.M., Miller, S.D., 2003. Intercropping irrigated corn with annual legumes for fall forage in the high plain. Agron. J. 95, 520-525, http://dx.doi. org/10.2134/agronj2003.5200.

Allen, V.G., Baker, M.T., Segarra, E., Brown, C.P., 2007. Integrated irrigated crop-livestock systems in dry climates. Agron. J. 99, 346-360, http://dx.doi.org/ 10.2134/agronj2006.0148.

Alleoni, L.R.F., Cambri, M.A., Caires, E.F., 2005. Chemical attributes of a cerrado Oxisol under no-tillage as affected by lime application methods and doses. Rev. Bras. Cienc. Solo 29, 923-934, http://dx.doi.org/10.1590/S010006832005000600010 (in Portuguese, with English abstract).

Amaral, A.S., Anghinoni, I., Hinrichs, R., Bertol, I., 2004. Movement of lime particles in the profile of an Inceptisol under no-tillage. Rev. Bras. Cienc. Solo 28, 359-367, http://dx.doi.org/10.1590/S0100-06832004000200014 (in Portuguese, with English abstract).

Ambrosano, E.J., Tanaka, R.T., Mascarenhas, H.A.A., van Raij, B., Quaggio, J.A., Cantarella, H., 1997. Leguminosas e oleaginosas. In: van Raij, B., et al. (Eds.), Recomendação de Adubação e Calagem para o Estado de São Paulo. Boletim Técnico 100. , 2nd ed. Inst. Agron., Campinas, SP, Brazil, pp. 189-203.

Borghi, E., Crusciol, C.A.C., Nascente, A.S., Souza, V.V., Martins, P.O., Mateus, G.P., Costa, C., 2013. Sorghum grain yield, forage biomass production and revenue as affected by intercropping time. Eur. J. Agron. 51, 130-139, http://dx.doi.org 10.1016/j.eja.2013.08.006

Braga, G.J., Pedreira, C.G.S., Herling, V.R., Luz, P.H.C., 2007. Grazing efficiency on marandu palisade grass as affected by herbage allowance. Pesqui. Agropecu. Bras. 42, 1641-1649, http://dx.doi.org/10.1590/S0100-204X2007001100017 (in Portuguese, with English abstract).

Briedis, C., Sá, J.C.D.M., Caires, E.F., Navarro, J.D.F., Inagaki, T.M., Boer, A., Neto, C.Q. Ferreira, A.D.O., Canalli, L.B., Dos Santos, J.B., 2012. Soil organic matter pools and carbon-protection mechanisms in aggregate classes influenced by surface liming in a no-till system. Geoderma 170, 80-88, http://dx.doi.org/10.1016/j. geoderma.2011.10.011.

Caires, E.F., Banzatto, D.A., Fonseca, A.F., 2000. Surface application of lime under a no-tillage system. Rev. Bras. Cienc. Solo 24, 161-169, http://dx.doi.org/10. 1590/S0100-06832000000100018 (in Portuguese, with English abstract).

Caires, E.F., Alleoni, L.R.F., Cambri, M.A., Barth, G., 2005. Surface application of lime for crop grain production under a no-till system. Agron. J. 97, 791-798, http:// dx.doi.org/10.2134/agronj2004.0207.

Caires, E.F., Churka, S., Garbuio, F.J., Ferrari, R.A., Morgano, M.A., 2006a. Soybean yield and quality as a function of lime and gypsum applications. Sci. Agric. 63, 370-379, http://dx.doi.org/10.1590/S0103-90162006000400008.

Caires, E.F., Cristovão, J., Corrêa, L., Churka, S., Barth, G., Garbuio, F.J., 2006b. Surface application of lime ameliorates subsoil acidity and improves root growth and yield of wheat in an acid soil under no-till system. Sci. Agric. 63, 502-509, http://dx.doi.org/10.1590/S0103-90162006000500013.

Caires, E.F., Barth, G., Garbuio, F.J., Churka, S., 2008a. Soil acidity, liming and soybean performance under no-till. Sci. Agric. 65, 532-540, http://dx.doi.org/ 10.1590/S0103-90162008000500013.

Caires, E.F., Garbuio, F.J., Churka, S., Barth, G., Corrêa, J.C.L., 2008b. Effects of soil acidity amelioration by surface liming on no-till corn, soybean, and wheat root growth and yield. Eur. J. Agron. 28, 57-64, http://dx.doi.org/10.1016/j.eja.2007. 05.002.

Caires, E.F., Pereira Filho, P.R.S., Zardo Filho, R., Feldhaus, I.C., 2008c. Soil acidity and aluminium toxicity as affected by surface liming and cover oat residues under a no-till system. Soil Use Manag. 24, 302-309, http://dx.doi.org/10.1111/ j.1475-2743.2008.00166.x.

Caires, E.F., Joris, H.A.W., Churka, S., 2011. Long-term effects of lime and gypsum additions on no-till corn and soybean yield and soil chemical properties in southern Brazil. Soil Use Manag. 27, 45-53, http://dx.doi.org/10.1111/j.14752743.2010.00310.x.

Caires, E.F., Haliski, A., Bini, A.R., Scharr, D.A., 2015. Surface liming and nitrogen fertilization for crop grain production under no-till management in Brazil. Eur. J. Agron. 66, 41-53, http://dx.doi.org/10.1016/j.eja.2015.02.008.

Cantarella, H., van Raij, B., Camargo, C.E.O., 1997. Cereais. In: van Raij, B., et al. (Eds.), Recomendação de Adubação e Calagem para o Estado de São Paulo. Boletim Técnico 100. , 2nd ed. Inst. Agron., Campinas, SP, Brazil, pp. 43-71.

Castro, G.S.A., Calonego, J.C., Crusciol, C.A.C., 2011. Soil physical properties in crop rotation systems as affected by liming materials. Pesqui. Agropecu. Bras. 46, 1690-1698, http://dx.doi.org/10.1590/S0100-204X2011001200015 (in Portuguese, with English abstract)

Castro, G.S.A., Crusciol, C.A.C., 2013a. Yield and mineral nutrition of soybean, maize, and congo signal grass as affected by limestone and slag. Pesqui. Agropecu. Bras. 48, 673-681, http://dx.doi.org/10.1590/S0100-204X2013000600013.

Castro, G.S.A., Crusciol, C.A.C., 2013b. Effects of superficial liming and silicate application on soil fertility and crop yield under rotation. Geoderma 195-196, 234-242, http://dx.doi.org/10.1016/j.geoderma.2012.12.006.

Ciotta, M.N., Bayer, C., Ernani, P.R., Fontoura, S.M.V., Wobeto, C., Albuquerque, J.A., 2004. Liming management and its effect on acidity components of an oxisol under no-tillage. Rev. Bras. Cienc. Solo 28, 317-326, http://dx.doi.org/10.1590/ S0100-06832004000200010 (in Portuguese, with English abstract).

CONAB, 2010. Cost of Agricultural Production, Available at: http://www.conab.gov. $\mathrm{br} / \mathrm{conab} /$ Main.php?MagID=3\&MagNo=39 (accessed 05.02.16.).

Corrêa, J.C., Bull, L.T., Crusciol, C.A.C., Moraes, M.H., 2009. Oxisol physical attributes affected by surface application of flue dust, aqueous lime, sewage sludges and limestone. Rev. Bras. Cienc. Solo 33, 263-272, http://dx.doi.org/10.1590/ S0100-06832009000200004 (in Portuguese, with English abstract).

Costa, K.A.P., Rosa, B., Oliveira, I.P., Custódio, D.P., Silva, D.C., 2005. Effect of seasonal climate condition on the dry matter production and bromatological composition of Brachiaria brizantha cv. Marandu. Cienc. Anim. Bras. 6, 187-193.

Costa, C.H.M., Crusciol, C.A.C., 2016. Long-term effects of lime and phosphogypsum application on tropical no-till soybean-oat-sorghum rotation and soil chemical properties. Eur. J. Agron. 74, 119-132, http://dx.doi.org/10.1016/j.eja.2015.12. 001.

Crusciol, C.A.C., Mateus, G.P., Pariz, C.M., Borghi, E., Costa, C., Silveira, J.P.F., 2011. Nutrition and sorghum hybrids yield with contrasting cycles intercropped with Marandu grass. Pesqu. Agropecu. Bras. 46, 1234-1240, http://dx.doi.org 10.1590/S0100-204X2011001000017 (in Portuguese, with English abstract).

Crusciol, C.A.C., Mateus, G.P., Nascente, A.S., Martins, P.O., Borghi, E., Pariz, C.M., 2012. An innovative crop-forage intercrop system: early cycle soybean cultivars and palisade grass. Agron. J. 104, 1085-1095, http://dx.doi.org/10. 2134/agronj2012.0002.

Crusciol, C.A.C., Nascente, A.S., Mateus, G.P., Borghi, E., Leles, E.P., Santos, N.C.B., 2013. Effect of intercropping on yields of corn with different relative maturities and palisade grass. Agron. J. 105, 599-606, http://dx.doi.org/10. 2134/agronj2012.0426.

Crusciol, C.A.C., Nascente, A.S., Mateus, G.P., Pariz, C.M., Martins, P.O., Borghi, E., 2014. Intercropping soybean and palisade grass for enhanced land use efficiency and revenue in a no till system. Eur. J. Agron. 58, 53-62, http://dx. doi.org/10.1016/j.eja.2014.05.001.

Crusciol, C.A.C., Nascente, A.S., Borghi, E., Soratto, R.P., Martins, P.O., 2015. Improving soil fertility and crop yield in a tropical region with palisade grass cover crops. Agron. J. 107, 2271-2280, http://dx.doi.org/10.2134/agronj14. 0603.

Derpsch, R., Friedrich, T., Kassam, A., Hongwen, L., 2010. Current status of adoption of no-till farming in the world and some of its main benefits. Int. J. Agric. Biol. Eng. 3, 1-26, http://dx.doi.org/10.3965/j.issn.1934-6344.2010.01.0-0. 
Ernani, P.R., Ribeiro, M.F.S., Bayer, C., 2004. Chemical modifications caused by liming below the limed layer in a predominantly variable charge acid soil. Commun. Soil Sci. Plant Anal. 35, 889-901, http://dx.doi.org/10.1081/CSS 120030365.

Fageria, N.K., dos Santos, A.B., Moreira, A., 2010. Yield, nutrient uptake, and changes in soil chemical properties as influenced by liming and iron application in common bean in a no-tillage system. Commun. Soil Sci. Plant Anal. 41, 1740-1749, http://dx.doi.org/10.1080/00103624.2010.489137.

Fox, D.G., Tedeschi, L.O., Tylutki, T.P., Russell, J.B., Van Amburgh, M.E., Chase, L.E., Pell, A.N., Overton, T.R., 2004. The Cornell net carbohydrate and protein system model for evaluating herd nutrition and nutrient excretion. Anim. Feed Sci. Technol. 112, 29-78, http://dx.doi.org/10.1016/j.anifeedsci.2003.10.006.

Franchini, J.C., Malavolta, E., Miyazawa, M., Pavan, M.A., 1999. Chemical changes in acid soils after application of plant residues. Rev. Bras. Cienc. Solo 23, 533-542, http://dx.doi.org/10.1590/S0100-06831999000300006 (in Portuguese, with English abstract).

Haynes, R.J., 1982. Effects of liming on phosphate availability in acid soil. A critical review. Plant Soil 68, 289-308.

Haynes, R.J., 1984. Ume and phosphate in the soil-plant system. Adv. Agron. 37, 249-315.

Islam, A., White, R.E., Chen, D., 2006. Nitrification activity in acid soils of north-eastern Victoria Australia, as affected by liming and phosphorus fertilisation. Aust. J. Soil Res. 44, 739-744, http://dx.doi.org/10.1071/SR06058.

Jaskulska, I., Jaskulski, D., Kobierski, M., 2014. Effect of liming on the change of some agrochemical soil properties in a long-term fertilization experiment. Plant Soil Environ. 60, 146-150.

Joris, H.A.W., Caires, E.F., Bini, A.R., Scharr, D.A., Haliski, A., 2013. Effects of soil acidity and water stress on corn and soybean performance under a no-till system. Plant Soil 365, 409-424, http://dx.doi.org/10.1007/s11104-012-14132 .

Kluthcouski, J., Aidar, H., 2003. Uso da integração lavoura-pecuária na recuperação de pastagens degradadas. In: Kluthcouski, J., et al. (Eds.), Integração lavoura-pecuária. Embrapa, Santo Antonio de Goiás, GO, Brazil, pp. 185-223.

Krause, H.H., 1965. Effect of ph on leaching losses of potassium applied to forest nursery soils. Soil Sci. Soc. Am. Proc. 29, 613-615.

Leal, R.M.P., Herpin, U., Fonseca, A.F., Firme, L.P., Montes, C.R., Melfi, A.J., 2009. Sodicity and salinity in a Brazilian Oxisol cultivated with sugarcane irrigated with wastewater. Agric. Water Manag. 96, 307-316.

Malavolta, E., Vitti, G.C., Oliveira, S.A., 1997. Avaliação do estado nutricional das plantas: Princípios e aplicações, 2nd ed. Assoc. Bras. Pesquisa Potassa Fosfato, Piracicaba, SP, Brazil.

Marsh, B.H., Grove, J.H., 1992. Plant and soil composition as affected by an alternative lime source containing sulfate. Soil Sci. Soc. Am. J. 56, 1831-1836, http://dx.doi.org/10.2136/sssaj1992.03615995005600060030x.

Martins, A.P., Anghinoni, I., Costa, S.E.V.G.A., Carlos, F.S., Nichel, G.H., Silva, R.A.P., Carvalho, P.C.F. 2014a. Amelioration of soil acidity and soybean yield after surface lime reapplication to a long-term no-till integrated crop-livestock system under varying grazing intensities. Soil Tillage Res. 144, 141-149 http:// dx.doi.org/10.1016/j.still.2014.07.019.

Martins, A.P., Costa, S.E.V.G.A., Anghinoni, I., Kunrath, T.R., Balerini, F., Cecagno, D., Carvalho, P.C.F., 2014b. Soil acidification and basic cation use efficiency in an integrated no-till crop-livestock system under different grazing intensities. Agric. Ecosyst. Environ. 195, 18-28, http://dx.doi.org/10.1016/j.agee.2014.05. 012.

Martins, A.P., Cecagno, D., Borin, J.B.M., Arnuti, F., Lochmann, S.H., Anghinoni, I., Bissani, C.A. Bayer C. Carvalho, P.C.F. 2016. Long-, medium- and short-term dynamics of soil acidity in an integrated crop-livestock system under different grazing intensities. Nutr. Cycl. Agroecosyst., http://dx.doi.org/10.1007/s10705015-9759-5 (published online: 08 January 2016).

Mateus, G.P., Borghi, E., Marques, R.R., Bôas, R.L.V., Crusciol, C.A.C., 2007. Sources and time of contact of mineral fertilizer with Brachiaria brizantha seeds as related with germination. Rev. Bras. Cienc. Solo 31, 177-183, http://dx.doi.org/ 10.1590/S0100-06832007000100018 (in Portuguese, with English abstract)

Mateus, G.P., Crusciol, C.A.C., Pariz, C.M., Borghi, E., Costa, C., Martello, J.M., Franzluebbers, A.J., Castilhos, A.M., 2016. Sidedress nitrogen application rates to sorghum intercropped with tropical perennial grasses. Agron. J. 108, 433-447, http://dx.doi.org/10.2134/agronj2015.0236.
Miyazawa, M., Pavan, M.A., Franchini, J.C., 2002. Evaluation of plant residues on the mobility of surface applied lime. Braz. Arch. Biol. Technol. 45, 251-256, http:// dx.doi.org/10.1590/S1516-89132002000300001.

Moreira, S.G., Kiehl, J.C., Prochnow, L.I., Pauletti, V., 2001. Liming under no-tillage and effects on soil acidity, soil nutrient availability and corn and soybean yield. Rev. Bras. Cienc. Solo 25, 71-81, http://dx.doi.org/10.1590/S010006832001000100008 (in Portuguese, with English abstract).

Murphy, J., Riley, J.P., 1962. A modified single solution method for the determination of phosphate in natural waters. Anal. Chim. Acta 27, 31-36.

Nascente, A.S., Crusciol, C.A.C., Cobucci, T., 2013. The no-tillage system and cover crops -alternatives to increase upland rice yield. Eur. J. Agron. 45, 124-131, http://dx.doi.org/10.1016/j.eja.2012.09.004.

Pariz, C.M., Andreotti, M., Buzetti, S., Bergamaschine, A.F., Ulian, N.A., Furlan, L.C., Meirelles, P.R.L., Cavasano, F.A., 2011a. Straw decomposition of nitrogen-fertilized grasses after intercropping with corn crop in irrigated integrated crop-livestock system. Rev. Bras. Cienc. Solo 35, 2029-2037, http:// dx.doi.org/10.1590/S0100-06832011000600019.

Pariz, C.M., Andreotti, M., Bergamaschine, A.F., Buzetti, S., Costa, N.R., Cavallini, M.C., Ulian, N.A., Luiggi, F.G., 2011b. Yield, chemical composition and chlorophyll relative content of Tanzania and Mombaça grasses irrigated and fertilized with nitrogen after corn intercropping. Rev. Bras. Zootec. 40, 728-738, http://dx.doi.org/10.1590/S1516-35982011000400005.

Sani, B.M., Danmowa, N.M., Sani, Y.A., Jaliya, M.M., 2011. Growth, yield and water use efficiency of maize-sorghum intercrop at Samaru Northern Guinea Savannah, Nigeria. Niger. J. Basic Appl. Sci. 19, 253-259.

Sato, S., Comerford, N.B., 2005. Influence of soil pH on inorganic phosphorus sorption and desorption in a humid Brazilian Ultisol. Rev. Bras. Cienc. Solo 29, 685-694, http://dx.doi.org/10.1590/S0100-06832005000500004.

Silva, C.A., Vale, F.R., 2000. Nitrate availability in Brazilian soils under effect of liming and sources and amounts of nitrogen. Pesqui. Agropecu. Bras. 35, 2461-2471, http://dx.doi.org/10.1590/S0100-204X2000001200017 (in Portuguese, with English abstract).

Soratto, R.P., Crusciol, C.A.C., 2007. Water-soluble cations in shoots of annual crops as affected by lime and phosphogypsum surface application. Rev. Bras. Cienc. Solo 31, 81-90, http://dx.doi.org/10.1590/S0100-06832007000100009 (in Portuguese, with English abstract).

Soratto, R.P., Crusciol, C.A.C., 2008a. Chemical soil attributes as affected by lime and phosphogypsum surface application in a recently established no-tillage system. Rev. Bras. Cienc. Solo 32, 675-688, http://dx.doi.org/10.1590/S010006832008000200022 (in Portuguese, with English abstract).

Soratto, R.P., Crusciol, C.A.C., 2008b. Dolomite and phosphogypsum surface application effects on annual crops nutrition and yield. Agron. J. 100, 261-270, http://dx.doi.org/10.2134/agrojnl2007.0120.

Sumner, M.E., 1995. Amelioration of subsoil acidity with minimum disturbance. In: Jayawardane, N.S., Stewart, B.A. (Eds.), Subsoil Management Techniques. Lewis Athens, Greek, pp. 147-185.

Surve, V.H., Arvadia, M.K., 2011. Performance of fodder sorghum (Sorghum bicolor L.), maize (Zea mays L.) and cowpea (Vigna unguiculata (L.) Walp.) under sole and intercropping systems. Int. J. Agric. Res. Rev. 2, 28-31.

Tiritan, C.S., Büll, L.T., Crusciol, C.A.C., Carmeis Filho, A.C.A., Fernandes, D.M., Nascente, A.S., 2016. Tillage system and lime application in a tropical region: soil chemical fertility and corn yield in succession to degraded pastures. Soil Tillage Res. 155, 437-447, http://dx.doi.org/10.1016/j.still.2015.06.012.

USDA, 2014. Keys to Soil Taxonomy: A Basic System of Soil Classification for Making and Interpreting Soil Surveys, twelfth edition. United States Department of Agriculture and Natural Resources Conservation Service, United States of America.

van Raij, B., Andrade, J.C., Cantarella, H., Quaggio, J.A., 2001. Análise química para avaliação da fertilidade de solos tropicais. Inst. Agron., Campinas, SP, Brazil.

van Soest, P.J., 1994. Nutritional Ecology of the Ruminant, second ed. Cornell University Press, Ithaca.

von Uexküll, H.R., Mutert, E., 1995. Global extent, development and economic impact of acid soils. Plant Soil 171,1-15, http://dx.doi.org/10.1007/ BF00009558.

Zobeck, T.M., Schillinger, W.F., 2010. Soil and Water Conservation Advances in the United States. Soil Science Society of America, Madison, USA 